Article

\title{
Why Chinese Financial Market Investors Do Not Care about Corporate Social Responsibility: Evidence from Mergers and Acquisitions
}

\author{
Minghui Li ${ }^{1,2}$, Faqin Lan ${ }^{1,2}$ and Fang Zhang 1,2,3,*(D) \\ 1 Faculty of Economics and Management, East China Normal University, Shanghai 200062, China; \\ mhli@sfs.edu.cn (M.L.); fqlan@jjx.ecnu.edu.cn (F.L.) \\ 2 Shanghai M\&A Financial Research Institute ECNU, Shanghai 200062, China \\ 3 Central China Development Research Institute, Henan University, Kaifeng 475001, China \\ * Correspondence: fzhang@finance.ecnu.edu.cn
}

Received: 16 May 2019; Accepted: 1 June 2019; Published: 4 June 2019

\begin{abstract}
We used the corporate social responsibility (CSR) data from Hexun Finance to analyze the three channels of market investor evaluation in the process of Chinese listed companies' mergers and acquisitions (M\&A). We found that: (1) because many CSR behaviors of Chinese listed companies are passive, driven by the environment, government, and regulatory authority, rather than proactive CSR for the long-term interests of the company, Chinese market investors are not concerned with the CSR performance of acquirers before the merger; (2) because passive CSR behavior cannot change the system risk and heterogeneity risk of the acquirers, CSR has no effect on the investor evaluation at the acquirer merger; (3) passive CSR can be used to evaluate public opinion, but CSR cannot change the market concerns of investors because investors only consider the systemic risks and heterogeneity rather than the social media evaluation of the company when pricing; and (4) with further study of the integration effect of CSR after M\&A, we found that CSR does not reduce the M\&A premium, only increases the return on asset (ROA) of the company within one year after M\&A, and does not improve the company's ROA for a long time. Our conclusions help explain why Chinese financial market investors are not concerned with the CSR performance of the M\&A party prior to M\&A.
\end{abstract}

Keywords: corporate social responsibility; mergers and acquisitions; passive CSR; market investor response

\section{Introduction}

Corporate social responsibility (CSR) is the responsibility of a company for its stakeholders in business operations, including employees, customers, suppliers, community groups, partners, shareholders, and investors. However, corporate social responsibility includes two types. One type of CSR stems from the mandatory requirements of regulators, the public, competitors, and the external environment, which we call 'passive CSR'. The other type of CSR stems from the active CSR company choices about long-term considerations, often closely related to consumers, employees, and shareholders. We call this 'active CSR' [1].

In China, with the rapid development of the economy and continuous improvements in the social legal system, people are expressing increasingly higher social responsibility requirements for enterprises. In the past, companies only needed to pay attention to the development of their own business. Now, in addition to more stimulating competition, companies are facing increasingly stringent regulatory requirements. The continuous improvement of China's social legal system-dsuch as the revision of the Labor Contract Law in 2007, the two amendments to the Consumer Rights 
Protection Act in 2009 and 2013, the 2014 Environmental Protection Law overhaul, and the Company Law 2018-means enterprises must increase their social responsibility.

In developed countries, the market mechanisms and institutional constraints in the environment are sufficient to drive enterprises to participate in social responsibility behavior [2]. However, this mechanism does not seem to exist in emerging economies like China [3]. Different from the active CSR of enterprises in developed countries, Chinese companies have a shorter development history. Many companies' CSR behaviors are not active with a focus on the long-term interests of enterprises, but are passive [4], as required by various regulatory authorities.

Passive CSR occurs because the company is affected by external pressure, so it cannot enhance the interests of the company like active CSR and create value for the company. Therefore, market investors may not produce a higher share price to passive CSR as they do with active CSR.

Based on this, we studied the reaction of Chinese market investors to CSR. In the research, we proceeded from the three transmission mechanisms of CSR that affect the investor's market reaction, which are often mentioned in the literature, and tested whether the CSR of Chinese enterprises influences the market investors' judgment of company value through three transmission mechanisms.

The contributions of this article are described in the following. First, in the sample selection, we selected a sample of Chinese listed companies, as an example of an emerging country, for research. Research on existing CSR has adopted samples from developed countries and were insufficiently concerned about developing and emerging countries. Given the different stages of economic development, the use of emerging country data may lead to different conclusions than those obtained for developed countries. Second, in the data selection, we chose two data sets. The first data set is companies' CSR data, which were compiled from the company's financial database through a web crawler. The second data set was the media evaluation data of listed companies. We adopted a new method to calculate positive social media report evaluations [5]. Existing social media reports on evaluation indicators [6-8] have not considered media-positive, -negative, and -neutral reports. We think that it is important to distinguish the subjective feelings of media reports in research. Third, in the study of the transmission mechanism, we propose three transmission channels that investors pay attention to according to the existing literature-systemic risk channels, heterogeneous risk channels, and social media-positive evaluation channels-and their impact on CSR adoption. This is also the main innovative contribution of this study. Fourth, unlike the conclusions of the existing literature, we concluded that, in China, the company's CSR does not influence investors' judgment on the value of the acquirer through these three channels because, in the past, Chinese companies' CSR behaviors were passive CSR behaviors driven by the government and regulatory authorities, and were not active CSR behaviors that the company considered for their long-term interests. Therefore, market investors generally evaluate the CSR of the acquirer.

The remainder of the paper is structured as follows. The second section reviews existing studies about how three channels of CSR might affect firm value or stock price, and proposes three hypotheses for the following empirical analysis. The third section describes data and introduces methodologies. The fourth section presents empirical results and some discussion of the findings. The last section concludes the paper and makes some policy implications, reveals several limitations of our study, and makes suggestions for future research.

\section{Literature Review and Hypotheses Development}

\subsection{Company Reputation Channel}

Many studies have indicated a significant impact of media reports on the stock price and market value of corporations [8-20]. Generally, companies with better CSR always receive more attention and more positive comments from the media, and spread of positive news about companies could drive up the stock price in the short term. Gurun and Butler [8] studied the effects of local media on the firm value of local companies by constructing their own media slant index. They found that the positive 
slant of local media has a significant relationship with firm value. Solomon [9] claimed that investor relations firms tend to generate more optimistic media information to promote the stock price of their clients around the earnings announcement date. Kim et al. [10] showed that socially responsible firms with high CSR have lower stock price crash risk when they commit to a high standard of transparency and engage in less bad news hoarding.

By contrast, pessimistic media reports could reduce companies' stock prices. Chan [11] showed that due to the slow reaction of investors to negative information, stock prices displayed a strong drift after bad news, then exhibiting an inverse increase later. Tetlock [12] constructed a media pessimism (MP) index from the Wall Street Journal, and estimated the relationships between MP and the stock market. They suggested that higher MP causes the pressure of stock price to decrease, and the lower stock returns then lead to a more pessimistic sentiment of investors. Tetlock et al. [13] found that negative news about corporations resulted in lower firm earnings, so negative reports about firms' fundamental financials could effectively predict companies' accounting earnings and stock returns. More recently, Aman [14] found that media coverage has a negative impact on stock price crash in Japan, which indicated that intensive media news on a firm cause strong reactions in the stock market to corporate news. Kim et al. [15] also confirmed the effects of negative media reports on lowering stock price through inter-regional analysis over 31 provinces within China.

Li et al. [16] and Oliveira et al. [17] indicated that the stock market is sensitive to public information in an era of social media, such as Internet media, and can be predicted by microblogging data, such as those from Twitter. Wu and Lin [18] investigated reactions of listed firms' investors to 10 different types of media news in Taiwan. Their results suggested seven news categories that can, to a large extent, positively or negatively affect both institutional and individual investor trading behaviors through optimistic or pessimistic words.

Based on the aforementioned research, affirmative media reports can enhance investors' trust in companies and risk tolerance to company failure by building a good corporate image. Thus, in merger and acquisition (M\&A) deals, acquiring companies with higher CSR tends to be favored and trusted by market investors, producing higher cumulative abnormal returns (CAR). However, media bias is ubiquitous in the economic and political fields [20], not only due to the supply motivation of media, but also to the demand motivation of related interest groups [21]. For instance, Gentzkow and Shapiro $[7,22]$ and Piotroski et al. [5] indicated that companies tend to release news or reporting with incentives for consumers' preferences to establish a good reputation and corporate image.

Other scholars indicated that media bias is greatly caused by advertising $[8,23,24]$. More specifically, Reuter and Zitzewitz [23] explored the positive relationship between recommendations of mutual funds and firms' advertisement expenditure on financial newspapers, and found that the independence of social media editors can be affected by commercial advertising. Rinallo and Basuroy [24] discovered that advertising investment plays a significant positive role in contexts of news reporting, especially in some specific industries, which were more dependent on social media. Gurun and Butler [8] revealed that local media tends to report more optimistic news about local firms to increase advertising revenue.

The media slant most probably misleads investors' behaviors and public sentiment. Cahan et al. [25] showed that firms' CSR initiatives are strongly related to media coverage, which caused "media company conspiracy" conduct. The more the firms act socially responsibly, the more favorable their media coverage. Their results indicated that firms can impact news reporting through the channel of CSR performance through a media slant in favor of high-CSR firms. Based on a micro-level survey, Yang et al. [26] investigated the influence of media reports on investor sentiment. Their findings showed a severe asymmetry of investors' trading decisions: investors pay more attention to positive news rather than negative news in a rising market, but diametrically in a declining market. To this extent, social media news reporting might be biased, so it might not be worth evaluating firms' value based on it for market investors. 


\subsection{Systematic Risk Channel}

Fama and French [27] proved that consumption assets can increase consumers' utility from holding such assets rather than from their pay-offs. Based on their theory, Cheung [28] proposed a perspective on a systematic risk channel CSR affecting stock markets. In this situation, investors favoring CSR companies or consumers' loyalty to CSR companies invest in CSR companies as consumption assets rather than investment assets, which can lower the systematic risk. As such, investors buy or sell these firms' stocks most likely because of their CSR performance rather than their risk-adjusted return performance or economic fundamentals. Analogously, consumers with a greater loyalty to CSR firms make the profit function less sensitive to changes in fundamental economics, which means the demand curve for CSR stocks is more inelastic. As a result of the inelasticity, CSR stocks are less sensitive to market-wide shocks and less prone to systemic risk. By constructing an industry equilibrium model, Albuquerque et al. [29] showed that CSR activities, as an investment in customer loyalty, can reduce systematic risk and improve firm value.

From the perspective of this channel, many other studies have implied that firms with a better CSR performance tend to have a lower systematic risk as well [30,31]. McAlister et al. [30] revealed that advertising and research and development $(R \& D)$ ability can lower firms' systematic risk, indicating that CSR might reduce systematic risk by influencing firms' advertising and R\&D activities. Luo and Bhattacharya [31] showed that systemic risk can be lowered by CSR performance via advertising and R\&D channels. For different industries, Jo and $\mathrm{Na}$ [32] investigated the relationship between CSR and firm risk in controversial industry sectors. They found that the effect of CSR on systematic risk reduction is more economically and statistically significant in controversial industries, such as those associated with alcohol, tobacco, gambling, and others. Additionally, Kim and Kim [33] and Park et al. [34] provided evidence that strengthening CSR actions can enhance shareholder value by reducing the systematic risk of firms' stocks in the restaurant industry. Oikonomou et al. [35] indicated a negative and weak relationship between CSR and systematic firm risk for a sample of 500 S\&P companies from 1992 to 2009. From the perspective of firm's cost of equity, the findings of El et al. [36] showed that firms with better CSR performance can obtain cheaper equity financing, which lowers the systematic risk of firms. Lee et al. [37] used the systematic risk as one of control variables to examine the relationship between CSR and corporate financial performance. Their results supported the idea that higher CSR can reduce the systemic risk as well.

\subsection{Idiosyncratic Risk Channel}

Some studies demonstrated that CSR can be viewed as a method for firms to accumulate social/moral capital over time [38-41]. Cheung [28] explained the reason for this is that firms participating in CSR activities can maintain or enhance a good relationship between stakeholders, with customers and investors by credibility, with employees and suppliers by trust, and with communities and regulators by a strong social image. Since firms with better CSR performance are expected to absorb external and internal shocks, idiosyncratic risk is reduced [31]. In particular, a good relationship with stakeholders, as insurance or protection for firms, can stabilize the demand and supply equilibrium in times of crisis, strengthen resilience against shocks, and enhance their recovery and sustainable growth.

Becchetti et al. [42] explored the linkage between idiosyncratic volatility and CSR, and found that idiosyncratic volatility is positively correlated with aggregate CSR and is negatively correlated with a CSR-specific (stakeholder) risk factor. Their conclusions were consistent with the argument that CSR reduces idiosyncratic risk via decreasing stakeholder well-being. Habib et al. [43] investigated CSR disclosures for a large sample of U.S. firms and found that CSR actions reduce the idiosyncratic risk for firms with a corporate customer concentration, providing evidence of firms with higher CSR scores having lower idiosyncratic risk. Rubin [44] argued that investing in CSR, as a form of "internal firm diversification", contributes to mitigating the idiosyncratic risk, which in turn contributes to improving financial performance. 
Different from the above studies that mainly focused on the positive aspects of CSR, Mishra and Modi [45] investigated how both positive and negative CSR affects firms' financial risk. They showed that CSR has a significant impact on idiosyncratic risk, with positive CSR lowering risk and negative CSR raising risk. Chen et al. [46] examined the influence of CSR on idiosyncratic risk in different market states by separating the sample period into an up market, down market, and correction market. They suggested that CSR engagement can be used as a risk management tool, since idiosyncratic risk can be significantly reduced by better CSR performance in all three market states. Using U.S. data, Hasan and Habib [47] revealed that a firm's idiosyncratic return volatility is not fully explained by firm-specific variables, but is also affected by regional social capital, influencing CSR to lower uncertainty about future cash flows and associated idiosyncratic return volatility.

From other perspectives, Koh et al. [48] suggested that firms with higher CSR can decrease the probability of facing lawsuits. Hockerts [49] elaborated that firms can increase profitability and reduce operating risk by integrating a thorough CSR strategy into business activities to build up a solid relationship with stakeholders. Based on China's case, Kao et al. [50] stated that practicing CSR can reduce the total risk as well. As a result, CSR, as a kind of insurance, could reduce the possibility of stock price crash when shocks happen. To this extent, Shiu and Yang [51] suggested that a good operation strategy and proper CSR execution can enhance firms' interactions with stakeholders, in order to reduce the idiosyncratic risk.

\subsection{Hypothesis Development}

The aforementioned studies provided evidence of three channels of CSR performance affecting stock prices or a firm's value, which further impact market investors. However, in China, the CSR consciousness of companies has awakened much later than in developed countries. Most companies might passively perform CSR, mostly due to public opinions or pressure from competitors, rather than taking active long-term action for firm value. Therefore, the motivations and incentives for CSR performance for Chinese firms are substantially different from firms in developed countries. Table 1 lists the categories of CSR activities of Chinses companies [4].

Table 1. Motivations of corporate social responsibility (CSR) disclosure in China.

\begin{tabular}{|c|c|c|c|}
\hline $\begin{array}{l}\text { Categories of } \\
\text { Motivations }\end{array}$ & Interested Party & Motivation & Type of CSR \\
\hline \multirow{3}{*}{ External pressure } & $\begin{array}{c}\text { Governments and } \\
\text { supervision departments }\end{array}$ & Compulsory requirements & $\begin{array}{l}\text { Environment and } \\
\text { regulatory norms }\end{array}$ \\
\hline & Social public and media & Social consensus & Charitable donations \\
\hline & Competitors & Against competitions & Fair competition \\
\hline \multirow{5}{*}{ Internal pressure } & Consumers & $\begin{array}{l}\text { Enhance customer loyalty } \\
\text { and stabilize market share }\end{array}$ & $\begin{array}{l}\text { Improve customers' } \\
\text { satisfaction }\end{array}$ \\
\hline & Employees & $\begin{array}{c}\text { Improve employee welfare } \\
\text { and productivity }\end{array}$ & $\begin{array}{l}\text { Employees and } \\
\text { labor union }\end{array}$ \\
\hline & Shareholders & Increase firm value & Financial targets \\
\hline & Creditors & $\begin{array}{l}\text { Lower external } \\
\text { financing costs }\end{array}$ & $\begin{array}{l}\text { Relationship } \\
\text { maintenance }\end{array}$ \\
\hline & $\begin{array}{l}\text { Governments and other } \\
\text { organizations }\end{array}$ & $\begin{array}{l}\text { Government support or } \\
\text { other political and } \\
\text { economic benefits }\end{array}$ & $\begin{array}{l}\text { Supply employment, } \\
\text { environment protection, } \\
\text { and community relations }\end{array}$ \\
\hline
\end{tabular}

Source from Li [4].

As a result, smart market investors in China are aware that the CSR actions of Chinese acquiring firms are passive responses caused by external pressure rather than active behaviors produced by internal motivations. Although CSR performance can improve public opinions or media news reporting, 
it cannot fundamentally and substantially reduce the systematic and idiosyncratic risk of Chinese firms. Smart investors can also recognize media bias or slants (media company conspiracy) to avoid evaluating firms' value through social media news reporting [52]. Above all, there is no valid evidence that Chinese investors evaluate firm value or stock price based on CSR performance via the channels of company reputation, systematic risk, and idiosyncratic risk. Therefore, we propose the following three hypotheses for M\&A deals in China:

Hypothesis 1 (H1): Firms with higher CSR tend not to have higher CAR, even though their reputation is improved, since CSR is a passive response rather than an active behavior.

Hypothesis 2 (H2): Firms with higher CSR tend not to reduce systematic risk and idiosyncratic risk.

Hypothesis 3 (H3): Firm performance after M\&A tends to not be significantly improved, since a passive CSR action cannot lower the acquisition premium.

\section{Data and Methods}

\subsection{Corporate Social Responsibility Data}

We used web crawler technology to download the CSR reports of listed companies from the Hexun Finance website. Based on the data disclosed in the social responsibility report of listed companies in China, Hexun Finance in 2013 established a set of secondary and tertiary indicators for shareholders; employee responsibility; supplier, customer, and consumer rights responsibility; environmental responsibility; and social responsibility to evaluate the enterprise. The compiled data cover almost 3500 listed companies in China from 2010 to 2017.

Table A1 lists social responsibility evaluation systems for listed companies in China. Through this scoring system, a social responsibility report score is assigned to listed companies every year. The higher the score, the better the listed company's CSR performance under the scoring system.

\subsection{Social Media Evaluation Data}

We used text analysis technology and machine learning technology to analyze the sentiment orientation of media reports in more than 3500 listed companies in Chinese financial news. After counting the number of negative emotional sentences, the number of neutral emotional sentences, and the number of positive emotional sentences in the body of the news report, the media evaluation was constructed by the following method:

Media Evaluation $=$ (positive reporting frequency - negative reporting frequency $) /$

$(1+$ positive reporting frequency + negative reporting frequency)

\subsection{Sample Description}

We extracted the M\&A sample from the China Stock Market \&Accounting Research (CSMAR) database. The data extraction period ranged from January 1, 2010 to December 31, 2017.

We selected the following as sample selection criteria:

(1) The acquirer was a listed firm and for which the M\&A transaction had been completed;

(2) A sample of M\&A target companies with a share of more than $50 \%$ of the target firm;

(3) A sample of stock prices that are available in the CSMAR database for acquirers so that we could calculate average abnormal returns and cumulative average abnormal returns;

(4) We isolated state-owned enterprises and private enterprises in the sample to examine the differences between the two; 
(5) We removed abnormal M\&A premium data, which mainly included the samples with M\&A premiums of less than negative $100 \%$.

\subsection{Econometric Methods}

\subsubsection{Calculating Abnormal Returns}

To simplify the calculation, we used the market model method to estimate the parameters of the normal rate of return model, and used this parameter to estimate the normal rate of return $\hat{R}_{i t}$ during the event window period. Based on this, the abnormal yield estimate $\left(\hat{A R}{ }_{i t}\right)$ of the sample company $i$ can be further calculated.

$$
\hat{A R_{i t}}=R_{i t}-\hat{R}_{i t}
$$

After calculating the abnormal rate of return in the event window, the results were grouped according to the CSR score of the year before the M\&A announcement date.

Based on the model in Equation (2), the average cumulative abnormal returns of sample firms can be calculated

$$
C A \hat{R}_{[-5, \mathrm{~T}]}=\sum_{t=-5}^{T} \hat{A R_{i t}}
$$

We calculated CAR [-5,5], CAR [-3,3], CAR [-2,2], CAR [-1,1], CAR [-3,1], and CAR [-2,1] from Equation (3) to measure the market reaction of investors.

\subsubsection{Identification Strategy}

After calculating the cumulative abnormal rate of return for each company, we conducted the following three-step test. The first step involved examining the impact of CSR on the cumulative abnormal return rate of mergers and acquisitions

$$
C A R_{i t}=\alpha+\beta_{1} C S R_{i t}+\sum_{j=1}^{M} \theta_{j} X_{i t}+\delta_{i}+\varepsilon_{i t}
$$

where $\beta_{1}$ measures the total effect of CSR on the market of investors' M\&A CAR evaluation.

The second step was to examine the impact of CSR on the channels that may affect the cumulative abnormal return rate of investors. The channel contains several channels that we have listed that affect risk, risk factors (market risk, scale risk, book market value ratio risk, heterogeneity risk), and market media evaluation

$$
\text { Channel }_{c i t}=\alpha+\beta_{c 2} \operatorname{CSR}_{i t}+\sum_{j=1}^{N} \theta_{j} X_{i t}+\delta_{i}+\mu_{i t}
$$

where $\beta_{c 2}$ measures the effects of CSR on channel variables (Channel ${ }_{c i t}$ ).

The third step was to test whether the channel effect exists

$$
C A R_{i t}=\alpha+\beta_{3} \operatorname{CSR}_{i t}+\sum_{c} \gamma_{c} \text { Channel }_{c i t}+\sum_{j=1}^{P} \theta_{j} X_{i t}+\delta_{i}+v_{i t}
$$

where Channel ${ }_{c i t}$ mainly includes systemic risk indicators $\left(\beta_{M}, \beta_{H M L}, \beta_{S M B}\right)$, idiosyncratic risk channels, and media evaluation channels; $\beta_{3}$ measures the direct effect of CSR on market investors' M\&A CAR evaluation; and $\gamma_{c} \beta_{c 2}$ measures the indirect effect of CSR's evaluation of CAR on market investors' M\&A through channels. In the above model, if any of $\beta_{1}, \beta_{c 2}$, and $\gamma_{c}$ are not significant, then the effect 
does not exist. If all $\beta_{1}, \beta_{c 2}$, and $\gamma_{c}$ are not significant, the CSR of the acquiring party has no influence on the market investor evaluation of subsequent M\&A.

The systematic risk indicators in the channel variables $\left(\beta_{M}, \beta_{H M L}\right.$, and $\left.\beta_{S M B}\right)$ are the market risk factor $\left(r_{M}-r_{f}, H M L, S M B\right)$ in the Fama-French three-factors model that constitute the company's market, $\mathrm{BM}$, and market value risk loading, respectively. Idiosyncratic risk is the residual variance of the Fama-French three-factors model using daily stock returns of the previous 12 months.

For the media evaluation in the channel variable, we used the calculation method in Section 3.2.

\section{Results and Discussion}

\subsection{Summary Statistics Results}

Table 2 provides the summary statistics of the key variables. The table shows that the sample company's CAR [-1,1], CAR [-3,3], CAR [-5,5], CAR [-2,2], CAR [-3,1], CAR [-2,1], and the average value are $0.03,0.04,0.05,0.04,0.02$, and 0.02 respectively. Although the numbers of days of different CAR are different, the value of CAR does not change much. The average CSR of the sample companies was 28.53 , the highest value was 82.58 , and the lowest value was 23.38 , indicating that CSR differences within Chinese listed companies are obvious.

Table 2. Summary statistics.

\begin{tabular}{|c|c|c|c|c|c|c|}
\hline Variable & Mean & p50 & Max & Min & Std Dev. & Obs \\
\hline$C A R[-1,1]$ & 0.03 & 0.01 & 0.30 & -0.31 & 0.09 & 1188 \\
\hline$C A R[-3,3]$ & 0.04 & 0.01 & 0.58 & -0.45 & 0.15 & 1188 \\
\hline CAR $[-5,5]$ & 0.05 & 0.01 & 0.82 & -0.55 & 0.18 & 1188 \\
\hline$C A R[-2,2]$ & 0.04 & 0.01 & 0.44 & -0.38 & 0.12 & 1188 \\
\hline$C A R[-3,1]$ & 0.02 & 0.01 & 0.15 & -0.14 & 0.05 & 1188 \\
\hline$C A R[-2,1]$ & 0.02 & 0.01 & 0.15 & -0.14 & 0.05 & 1188 \\
\hline CSR & 28.53 & 23.38 & 82.58 & 0.00 & 17.86 & 1188 \\
\hline Media evaluation & 33.04 & 35.74 & 81.28 & -38.81 & 19.51 & 1188 \\
\hline$\beta_{M-3 f a c t o r s}$ Model & 1.47 & 1.25 & 3.83 & -1.26 & 0.81 & 1188 \\
\hline$\beta_{H M L}-3$ factors Model & 1.88 & 0.34 & 26.77 & -5.98 & 3.21 & 1188 \\
\hline$\beta_{S M B}$-3factors Model & 1.15 & 0.93 & 19.19 & -3.52 & 2.14 & 1188 \\
\hline Idio-risk-3factors Model & 2.23 & 1.73 & 9.01 & -1.30 & 2.09 & 984 \\
\hline$\beta_{M}-5$ factors Model & 1.46 & 1.37 & 4.05 & -0.59 & 0.53 & 1188 \\
\hline$\beta_{H M L}-5$ factors Model & 2.18 & 1.86 & 31.67 & -18.49 & 3.52 & 1188 \\
\hline$\beta_{S M B}-5$ factors Model & 1.43 & 0.84 & 38.95 & -16.88 & 5.91 & 1188 \\
\hline$\beta_{R M W}-5$ factors Model & -0.28 & 0.14 & 32.91 & -47.19 & 13.19 & 1188 \\
\hline$\beta_{C M A}$-5factors Model & -2.96 & -2.15 & 16.11 & -15.25 & 4.01 & 1188 \\
\hline Idio-risk-5factors Model & 1.89 & 1.62 & 7.58 & -1.28 & 1.68 & 1032 \\
\hline Firm Age & 17.54 & 17.29 & 66.39 & 4.27 & 5.29 & 1188 \\
\hline LNTA & 1.68 & 1.57 & 6.55 & -2.20 & 1.18 & 1188 \\
\hline Cash ratio & 0.67 & 0.32 & 26.14 & 0.00 & 1.37 & 1188 \\
\hline Liability ratio & 0.48 & 0.49 & 1.06 & 0.03 & 0.20 & 1188 \\
\hline TobinQ & 2.08 & 1.60 & 42.39 & 0.09 & 2.46 & 1188 \\
\hline MAValue & 6.58 & 0.95 & 2358.15 & -30.72 & 69.79 & 1188 \\
\hline Friendly & 0.97 & 1.00 & 1.00 & 0.00 & 0.16 & 1188 \\
\hline Vertical & 0.74 & 1.00 & 1.00 & 0.00 & 0.44 & 1188 \\
\hline MAPremium1 & 33.70 & 188.31 & -100.00 & -0.00 & 1303.29 & 1188 \\
\hline MAPremium2 & 30.83 & 204.26 & -100.00 & -0.00 & 1338.24 & 1188 \\
\hline DROA1 & -0.01 & -0.01 & 0.45 & -1.58 & 0.07 & 1053 \\
\hline$D R O A 2$ & -0.01 & -0.01 & 0.34 & -0.26 & 0.05 & 849 \\
\hline$D R O A 3$ & -0.02 & -0.01 & 0.27 & -0.42 & 0.06 & 562 \\
\hline DROA4 & -0.02 & -0.02 & 0.23 & -0.27 & 0.06 & 325 \\
\hline DROA5 & -0.03 & -0.02 & 0.20 & -0.48 & 0.08 & 173 \\
\hline SOE & 0.42 & 0.00 & 1.00 & 0.00 & 0.49 & 1188 \\
\hline
\end{tabular}


Table 2 reports the summary statistics of the key variables. CAR is the cumulative abnormal returns of M\&A. CAR [-1,1], CAR [-2,2], CAR [-3,3], and CAR [-5,5] are the defined CAR of the day before and after the announcement day, two days before and after the announcement day, three days before and after the announcement day, and five days before and after the announcement day, respectively. CAR $[-3,1]$ defines the CAR three days before and one day after the announcement day, CAR $[-2,1]$ defines the CAR two days before and one day after the announcement day, Media evaluation is defined as (positive report frequency - negative report frequency)/ $(1+$ positive report frequency + negative report frequency), CSR is defined as the corporate social responsibility score of the Hexun Finance website, and the Cash ratio is defined as the cash and cash equivalents divided by current assets. $\beta_{M}$-3factors Model, $\beta_{H M L}-3$ factors Model, $\beta_{S M B}$-3factors Model, and Idio-risk-3factors Model are the regression coefficients of $r_{M}-r_{f}, H M L, S M B$, and the residual variance of the Fama-French three-factors model using the daily stock returns of the previous 12 months, respectively; $\beta_{M}-5$ factors Model, $\beta_{H M L}-5$ factors Model, $\beta_{S M B}-5$ factors Model, $\beta_{R M W}$-5factors Model, $\beta_{C M A}$-5factors Model, and Idio-risk-5factors Model define the regression coefficients of $r_{M}-r_{f}, H M L, S M B, R M W, C M A$, and the residual variance of the Fama-French five-factors model using daily stock returns of the previous 12 months, respectively; Firm Age is the year in which the transaction occurred minus the established year; LNTA is the natural logarithm of total assets; Cash Ratio represents the current assets divided by current liabilities; Liability Ratio represents the total liabilities divided by total assets; Tobin $Q$ is the market value divided by total assets; MAValue is the deal value of M\&A, Unit: billion RMB; Friendly is a dummy variable indicating whether the merger is a malicious acquisition and equals 1 for a friendly acquisition and 0 for a malicious acquisition; and Vertical is a dummy variable of a vertical acquisition. MAPremium1 and MAPremium2 are proxy variables for the M\&A premium. The former uses the expense value over the portion of underlying value in percentage form to perform the calculation and the latter uses all expenses exceeding the underlying value in percentage form to perform the calculation. DROA1, $D R O A 2, D R O A 3, D R O A 4$, and DROA5 are the defined return on asset (ROA) one year after the M\&A transaction to the ROA one year before the M\&A transaction. $S O E$ is a dummy variable indicating whether the merger is a state-owned enterprise, equaling 1 for a state-owned enterprise and 0 for a private enterprise. For the definition and calculation method of each variable, see Appendix $A$ and Table A2 for details.

\subsection{Main Results}

Table 3 details the impact of CSR on the M\&A company. From the conclusion of the model in the table, CSR has no significant effect on the CAR of the acquirers after controlling for the year and industry dummy variables. This shows that the CSR of the acquirers has no significant impact on market investors' concerns. This conclusion is established in CAR $[-5,5]$, CAR $[-3,3]$ and CAR $[-1,1]$. Meanwhile, without controlling the year and industry fixed effects, the Adj. $R^{2}$ of model 1-2 is 0.039 , which is very low. After the year is fixed, the Adj. $R^{2}$ of model 3 increases to 0.096 . Further controlling the industry's fixed effects, the Adj. $R^{2}$ of model 4 increases to 0.111 . From the sequential increase of Adj. $R^{2}$, our empirical results should be model 4 with higher value of Adj. $R^{2}$, which controls the year and industry fixed effects. This situation also happens in the empirical results of CAR $[-3,3]$ and CAR $[-1,1]$. Therefore, we should take the results of model 4 , model 8 , and model 12 as the main conclusions of this paper. 
Table 3. Empirical impact of CSR on CAR.

\begin{tabular}{|c|c|c|c|c|c|c|c|c|c|c|c|c|}
\hline \multirow{2}{*}{ Variable } & \multicolumn{4}{|c|}{ CAR $[-5,5]$} & \multicolumn{4}{|c|}{ CAR $[-3,3]$} & \multicolumn{4}{|c|}{ CAR $[-1,1]$} \\
\hline & Model 1 & Model 2 & Model 3 & Model 4 & Model 5 & Model 6 & Model 7 & Model 8 & Model 9 & Model 10 & Model 11 & Model 12 \\
\hline CSR & $\begin{array}{c}-0.001 \text { * } \\
(-1.93)\end{array}$ & $\begin{array}{c}-0.001 \text { ** } \\
(-2.11)\end{array}$ & $\begin{array}{l}-0.000 \\
(-1.49)\end{array}$ & $\begin{array}{l}-0.000 \\
(-1.26)\end{array}$ & $\begin{array}{l}-0.000 \\
(-1.70)\end{array}$ & $\begin{array}{l}-0.000 \\
(-1.85)\end{array}$ & $\begin{array}{l}-0.000 \\
(-1.27)\end{array}$ & $\begin{array}{l}-0.000 \\
(-0.95)\end{array}$ & $\begin{array}{l}-0.000 \\
(-1.21)\end{array}$ & $\begin{array}{l}-0.000 \\
(-1.27)\end{array}$ & $\begin{array}{l}-0.000 \\
(-0.80)\end{array}$ & $\begin{array}{l}-0.000 \\
(-0.34)\end{array}$ \\
\hline Firm age & $\begin{array}{l}0.000 \\
(0.02)\end{array}$ & $\begin{array}{l}0.000 \\
(0.02)\end{array}$ & $\begin{array}{l}-0.000 \\
(-0.11)\end{array}$ & $\begin{array}{l}0.000 \\
(0.53)\end{array}$ & $\begin{array}{l}0.000 \\
(0.10)\end{array}$ & $\begin{array}{l}0.000 \\
(0.11)\end{array}$ & $\begin{array}{l}-0.000 \\
(-0.06)\end{array}$ & $\begin{array}{l}0.000 \\
(0.61)\end{array}$ & $\begin{array}{l}0.000 \\
(0.09)\end{array}$ & $\begin{array}{l}0.000 \\
(0.09)\end{array}$ & $\begin{array}{l}-0.000 \\
(-0.08)\end{array}$ & $\begin{array}{l}0.000 \\
(0.85)\end{array}$ \\
\hline LNTA & $\begin{array}{l}-0.009 \\
(-1.46)\end{array}$ & $\begin{array}{l}-0.009 \\
(-1.47)\end{array}$ & $\begin{array}{c}-0.012 * \\
(-1.94)\end{array}$ & $\begin{array}{c}-0.015^{* *} \\
(-2.21)\end{array}$ & $\begin{array}{c}-0.010 * * \\
(-2.04)\end{array}$ & $\begin{array}{c}-0.010 * * \\
(-2.01)\end{array}$ & $\begin{array}{c}-0.012 * * \\
(-2.37)\end{array}$ & $\begin{array}{c}-0.014 \text { *** } \\
(-2.75)\end{array}$ & $\begin{array}{c}-0.006 \text { ** } \\
(-2.11)\end{array}$ & $\begin{array}{c}-0.006 \text { ** } \\
(-1.96)\end{array}$ & $\begin{array}{c}-0.007 * * \\
(-2.20)\end{array}$ & $\begin{array}{c}-0.009^{* * *} \\
(-2.74)\end{array}$ \\
\hline Cash ratio & $\begin{array}{l}-0.002 \\
(-0.43)\end{array}$ & $\begin{array}{l}-0.002 \\
(-0.23)\end{array}$ & $\begin{array}{l}0.001 \\
(0.13)\end{array}$ & $\begin{array}{l}0.002 \\
(0.34)\end{array}$ & $\begin{array}{l}-0.003 \\
(-0.79)\end{array}$ & $\begin{array}{l}-0.003 \\
(-0.44)\end{array}$ & $\begin{array}{l}-0.000 \\
(-0.05)\end{array}$ & $\begin{array}{l}0.001 \\
(0.19)\end{array}$ & $\begin{array}{c}-0.004 * \\
(-1.73)\end{array}$ & $\begin{array}{l}-0.004 \\
(-1.03)\end{array}$ & $\begin{array}{l}-0.002 \\
(-0.69)\end{array}$ & $\begin{array}{l}-0.001 \\
(-0.39)\end{array}$ \\
\hline Liability ratio & $\begin{array}{l}0.005 \\
(0.14)\end{array}$ & $\begin{array}{l}0.005 \\
(0.12)\end{array}$ & $\begin{array}{l}0.005 \\
(0.13)\end{array}$ & $\begin{array}{l}0.029 \\
(0.67)\end{array}$ & $\begin{array}{l}0.006 \\
(0.20)\end{array}$ & $\begin{array}{l}0.006 \\
(0.17)\end{array}$ & $\begin{array}{l}0.005 \\
(0.15)\end{array}$ & $\begin{array}{l}0.024 \\
(0.70)\end{array}$ & $\begin{array}{l}0.001 \\
(0.03)\end{array}$ & $\begin{array}{l}0.001 \\
(0.03)\end{array}$ & $\begin{array}{l}-0.001 \\
(-0.03)\end{array}$ & $\begin{array}{l}0.014 \\
(0.70)\end{array}$ \\
\hline Tobin $Q$ & $\begin{array}{c}0.007^{* * *} \\
(3.04)\end{array}$ & $\begin{array}{c}0.007^{* *} \\
(2.01)\end{array}$ & $\begin{array}{l}0.003 \\
(0.65) \\
\end{array}$ & $\begin{array}{l}0.000 \\
(0.11) \\
\end{array}$ & $\begin{array}{c}0.006^{* * *} \\
(3.05)\end{array}$ & $\begin{array}{c}0.006^{*} \\
(1.86)\end{array}$ & $\begin{array}{l}0.002 \\
(0.56) \\
\end{array}$ & $\begin{array}{l}0.000 \\
(0.08) \\
\end{array}$ & $\begin{array}{c}0.003 * * \\
(2.53)\end{array}$ & $\begin{array}{c}0.003 * \\
(1.68)\end{array}$ & $\begin{array}{l}0.001 \\
(0.35)\end{array}$ & $\begin{array}{l}-0.000 \\
(-0.13)\end{array}$ \\
\hline MAValue & $\begin{array}{c}0.000 * * * \\
(3.08)\end{array}$ & $\begin{array}{l}0.000 \\
(1.51)\end{array}$ & $\begin{array}{l}0.000 \\
(1.46)\end{array}$ & $\begin{array}{l}0.000 \\
(1.54)\end{array}$ & $\begin{array}{c}0.000 * * * \\
(3.91)\end{array}$ & $\begin{array}{c}0.000^{* *} \\
(1.99)\end{array}$ & $\begin{array}{c}0.000^{* *} \\
(1.97)\end{array}$ & $\begin{array}{c}0.000^{* *} \\
(2.11)\end{array}$ & $\begin{array}{c}0.000^{* * *} \\
(4.46)\end{array}$ & $\begin{array}{c}0.000^{* *} \\
(2.47)\end{array}$ & $\begin{array}{c}0.000^{* *} \\
(2.50)\end{array}$ & $\begin{array}{c}0.000 * * * \\
(2.73)\end{array}$ \\
\hline Friendly & $\begin{array}{c}0.057^{*} \\
(1.66)\end{array}$ & $\begin{array}{c}0.057^{* * *} \\
(3.02)\end{array}$ & $\begin{array}{c}0.033^{*} \\
(1.78)\end{array}$ & $\begin{array}{l}0.031 \\
(1.62)\end{array}$ & $\begin{array}{c}0.052 * \\
(1.91)\end{array}$ & $\begin{array}{c}0.052 * * * \\
(3.96)\end{array}$ & $\begin{array}{c}0.031^{* *} \\
(2.21)\end{array}$ & $\begin{array}{c}0.030^{* *} \\
(2.00)\end{array}$ & $\begin{array}{c}0.040^{* *} \\
(2.36)\end{array}$ & $\begin{array}{c}0.040^{* * *} \\
(4.21)\end{array}$ & $\begin{array}{c}0.026^{* *} \\
(2.48)\end{array}$ & $\begin{array}{c}0.025^{* *} \\
(2.41)\end{array}$ \\
\hline Vertical & $\begin{array}{c}0.042 * * * \\
(3.44)\end{array}$ & $\begin{array}{c}0.042 * * * \\
(4.12)\end{array}$ & $\begin{array}{c}0.0366^{* * *} \\
(3.52)\end{array}$ & $\begin{array}{c}0.035^{* * *} \\
(3.24)\end{array}$ & $\begin{array}{c}0.032 * * * \\
(3.28)\end{array}$ & $\begin{array}{c}0.032 * * * \\
(3.77)\end{array}$ & $\begin{array}{c}0.027^{* * *} \\
(3.17)\end{array}$ & $\begin{array}{c}0.026^{* * *} \\
(2.92)\end{array}$ & $\begin{array}{c}0.014^{* *} \\
(2.24)\end{array}$ & $\begin{array}{c}0.014^{* *} \\
(2.57)\end{array}$ & $\begin{array}{c}0.010^{* *} \\
(2.01)\end{array}$ & $\begin{array}{c}0.010^{*} \\
(1.80)\end{array}$ \\
\hline Constant & $\begin{array}{l}-0.022 \\
(-0.50) \\
\end{array}$ & $\begin{array}{l}-0.022 \\
(-0.63) \\
\end{array}$ & $\begin{array}{l}-0.026 \\
(-0.76) \\
\end{array}$ & $\begin{array}{c}-0.079 * * \\
(-1.98) \\
\end{array}$ & $\begin{array}{l}-0.019 \\
(-0.55) \\
\end{array}$ & $\begin{array}{l}-0.019 \\
(-0.69) \\
\end{array}$ & $\begin{array}{l}-0.022 \\
(-0.80) \\
\end{array}$ & $\begin{array}{c}-0.065^{* *} \\
(-2.02) \\
\end{array}$ & $\begin{array}{l}-0.009 \\
(-0.41) \\
\end{array}$ & $\begin{array}{l}-0.009 \\
(-0.51) \\
\end{array}$ & $\begin{array}{l}-0.010 \\
(-0.58) \\
\end{array}$ & $\begin{array}{l}-0.031 \\
(-1.46) \\
\end{array}$ \\
\hline Year FE & No & No & Yes & Yes & No & No & Yes & Yes & No & No & Yes & Yes \\
\hline Industry FE & No & No & No & Yes & No & No & No & Yes & No & No & No & Yes \\
\hline Cluster & No & Yes & Yes & Yes & No & Yes & Yes & Yes & No & Yes & Yes & Yes \\
\hline N & 1188 & 1188 & 1188 & 1188 & 1188 & 1188 & 1188 & 1188 & 1188 & 1188 & 1188 & 1188 \\
\hline Adj. $R^{2}$ & 0.039 & 0.039 & 0.096 & 0.111 & 0.047 & 0.047 & 0.112 & 0.125 & 0.042 & 0.042 & 0.110 & 0.126 \\
\hline
\end{tabular}


Table 4 provides the test results of CSR for the three channels proposed in this paper. From the conclusion of the model in Table 4, we find that CSR can significantly improve the social media slant to acquirers. Our finding is consistent with conclusions of Gurun and Butler [8], Solomon [9], Tetlock [12], and Tetlock et al. [13] for US, Aman [14] for Japan, Kim et al. [15] for China, Wu and Lin [18] for Taiwan. However, CSR is not significant for acquirers' systemic risk indicators $\left(\beta_{M}-3\right.$ factors Model, $\beta_{H M L}-3$ factors Model, and $\beta_{S M B}-3$ factors Model) or for idiosyncratic risk indicators (Idio-risk-3factors Model), which is contrary to the findings of existing research. Since many scholars (Cheung [28], Albuquerque et al. [29], McAlister et al. [30], Jo and Na [32], Oikonomou et al. [35], Lee et al. [37] with US sample, and Luo and Bhattacharya. [31], Kim and Kim [33], Park et al. [34], El et al. [36] with worldwide sample) find that CSR can significantly reduce systematic risk. In addition, other scholars (Becchetti et al. [42], Habib et al. [43], Mishra and Modi [45], Hasan and Habib [47], Koh et al. [48], Shiu and Yang [51] with US sample, Chen et al. [46] with Taiwan sample, and Koh et al. [48] with worldwide sample) find that CSR can lower idiosyncratic risk as well. Generally speaking, most studies based on US or worldwide cases come to a conclusion of CSR lowering systematic risk and idiosyncratic risk, which our study do not. However, our results based on China's sample prove the aforementioned hypothesis $\mathrm{H} 2$, which means most CSR actions in China are passive CSR rather than active CSR. Based on above mentioned observations, the hypotheses $\mathrm{H} 1$ and $\mathrm{H} 2$ are verified from the results of Tables 3 and 4 .

Table 4. Impact of CSR on channels.

\begin{tabular}{|c|c|c|c|c|c|}
\hline \multirow{2}{*}{ Variable } & \multicolumn{3}{|c|}{ Channel One } & \multirow{2}{*}{$\begin{array}{l}\text { Channel Two } \\
\text { Idio-risk-3factors } \\
\text { Model }\end{array}$} & \multirow{2}{*}{$\begin{array}{c}\text { Channel Three } \\
\text { Media } \\
\text { Evaluation }\end{array}$} \\
\hline & $\begin{array}{c}\beta_{M}-3 \text { factors } \\
\text { Model }\end{array}$ & $\begin{array}{c}\beta_{H M L}-3 \text { factors } \\
\text { Model }\end{array}$ & $\begin{array}{c}\beta_{S M B^{-3 f a c t o r s}} \\
\text { Model }\end{array}$ & & \\
\hline CSR & $\begin{array}{l}0.000 \\
(0.57)\end{array}$ & $\begin{array}{l}0.003 \\
(1.12)\end{array}$ & $\begin{array}{l}-0.001 \\
(-0.52)\end{array}$ & $\begin{array}{l}0.000 \\
(0.89)\end{array}$ & $\begin{array}{c}0.128^{* * *} \\
(3.68)\end{array}$ \\
\hline Firm age & $\begin{array}{l}-0.001 \\
(-0.35)\end{array}$ & $\begin{array}{l}0.002 \\
(0.16)\end{array}$ & $\begin{array}{l}-0.003 \\
(-0.45)\end{array}$ & $\begin{array}{l}-0.000 \\
(-0.99)\end{array}$ & $\begin{array}{l}0.079 \\
(0.70)\end{array}$ \\
\hline LNTA & $\begin{array}{l}0.022 \\
(1.23)\end{array}$ & $\begin{array}{l}0.008 \\
(0.12)\end{array}$ & $\begin{array}{c}-0.225^{* * *} \\
(-4.89)\end{array}$ & $\begin{array}{l}0.000 \\
(0.57)\end{array}$ & $\begin{array}{c}2.870 * * * \\
(3.63)\end{array}$ \\
\hline Cash ratio & $\begin{array}{l}-0.004 \\
(-0.50)\end{array}$ & $\begin{array}{l}0.048 \\
(1.39)\end{array}$ & $\begin{array}{l}0.027 \\
(1.31)\end{array}$ & $\begin{array}{l}0.000 \\
(1.02)\end{array}$ & $\begin{array}{l}-0.816 \\
(-1.49)\end{array}$ \\
\hline $\begin{array}{l}\text { Liability } \\
\text { ratio }\end{array}$ & $\begin{array}{l}-0.076 \\
(-0.85)\end{array}$ & $\begin{array}{c}0.710 * \\
(1.79)\end{array}$ & $\begin{array}{c}0.693 * * \\
(2.56)\end{array}$ & $\begin{array}{c}0.013 * * * \\
(2.94)\end{array}$ & $\begin{array}{c}-10.339 * * \\
(-2.07)\end{array}$ \\
\hline Tobin $Q$ & $\begin{array}{c}-0.020 * * \\
(-2.06)\end{array}$ & $\begin{array}{l}0.030 \\
(0.76)\end{array}$ & $\begin{array}{l}-0.006 \\
(-0.24)\end{array}$ & $\begin{array}{l}0.001 \\
(1.46)\end{array}$ & $\begin{array}{l}-0.471 \\
(-1.18)\end{array}$ \\
\hline MAValue & $\begin{array}{l}0.000 \\
(1.01)\end{array}$ & $\begin{array}{l}-0.000 \\
(-1.21)\end{array}$ & $\begin{array}{c}-0.000 * \\
(-1.83)\end{array}$ & $\begin{array}{l}-0.000 \\
(-1.36)\end{array}$ & $\begin{array}{l}-0.000 \\
(-0.19)\end{array}$ \\
\hline Friendly & $\begin{array}{l}-0.050 \\
(-0.79)\end{array}$ & $\begin{array}{l}-0.171 \\
(-0.88)\end{array}$ & $\begin{array}{l}-0.031 \\
(-0.23)\end{array}$ & $\begin{array}{l}-0.001 \\
(-0.85)\end{array}$ & $\begin{array}{l}-0.401 \\
(-0.13)\end{array}$ \\
\hline Vertical & $\begin{array}{l}0.021 \\
(0.83)\end{array}$ & $\begin{array}{l}0.120 \\
(1.07)\end{array}$ & $\begin{array}{l}0.066 \\
(1.02)\end{array}$ & $\begin{array}{l}-0.001 \\
(-0.43)\end{array}$ & $\begin{array}{l}-1.517 \\
(-1.29)\end{array}$ \\
\hline Constant & $\begin{array}{c}2.616^{* * *} \\
(26.87)\end{array}$ & $\begin{array}{c}2.767^{* * * *} \\
(6.42)\end{array}$ & $\begin{array}{c}3.283^{* * *} \\
(13.18)\end{array}$ & $\begin{array}{c}0.267^{* * *} \\
(51.44)\end{array}$ & $\begin{array}{c}19.487^{* * *} \\
(3.19)\end{array}$ \\
\hline Year FE & Yes & Yes & Yes & Yes & Yes \\
\hline Industry FE & Yes & Yes & Yes & Yes & Yes \\
\hline Cluster & Yes & Yes & Yes & Yes & Yes \\
\hline$N$ & 1188 & 1188 & 1188 & 1188 & 1188 \\
\hline Adj. $R^{2}$ & 0.751 & 0.681 & 0.698 & 0.975 & 0.168 \\
\hline
\end{tabular}

Note: $t$-statistics in parentheses: ${ }^{*} p<0.1,{ }^{* *} p<0.05,{ }^{* * *} p<0.01$. 
Table 5 provides the analysis of CSR's evaluation of M\&A by market investors through the three channels proposed in this paper. From the empirical results, after controlling for the year and industry dummy variables, CSR's impact on investors' M\&A market evaluation is not significant, indicating that a direct effect of CSR on M\&A evaluation does not exist. $\beta_{M}-3$ factors Model in systemic risk is significant, whereas $\beta_{H M L}$-3factors Model and $\beta_{S M B}$-3factors Model are not significant, and the company idiosyncratic risk coefficient is significant, indicating that the market investors' judgment on the M\&A value of M\&A companies is only related to the market risk and the company's own idiosyncratic risk in the systemic risk of the M\&A company, and is unrelated to the BM risk and market value risk in the systemic risk. That is, regardless of the BM risk and market value assumed by the M\&A company, market investors will not change their judgment of the value of M\&A. Market investors only judge the value of M\&A if the market risk assumed by the M\&A company and the risk of the company's own heterogeneity are high.

Another channel variable we considered, media evaluation, is not significant for the investor M\&A evaluation coefficient, indicating that market investors are not guided by the positive evaluation of market media when judging the value of M\&A-market investors are not affected by the positive effects of public opinion evaluation due to the better CSR of the M\&A company.

Combining the data of Tables 3-5, we drew the following conclusions. First, CSR does not affect the value judgment of Chinese market investors in subsequent mergers and acquisitions; second, the value judgment of M\&A by Chinese market investors mainly depends on the heterogeneity risk of the M\&A company and the market risk in the systemic risk, and does not depend on the BM risk, the market value risk, or the positive media evaluation; third, although CSR can create a positive image of the company and improve the public's positive assessment of mergers and acquisitions, the CSR of the acquiring company cannot be transformed into higher M\&A value in investors' judgment because the factors affecting investors' evaluation of M\&A (such as market risk of systemic risk and heterogeneity of risk) cannot be changed. 
Table 5. Impact of acquirer's CSR on the CAR through three channels.

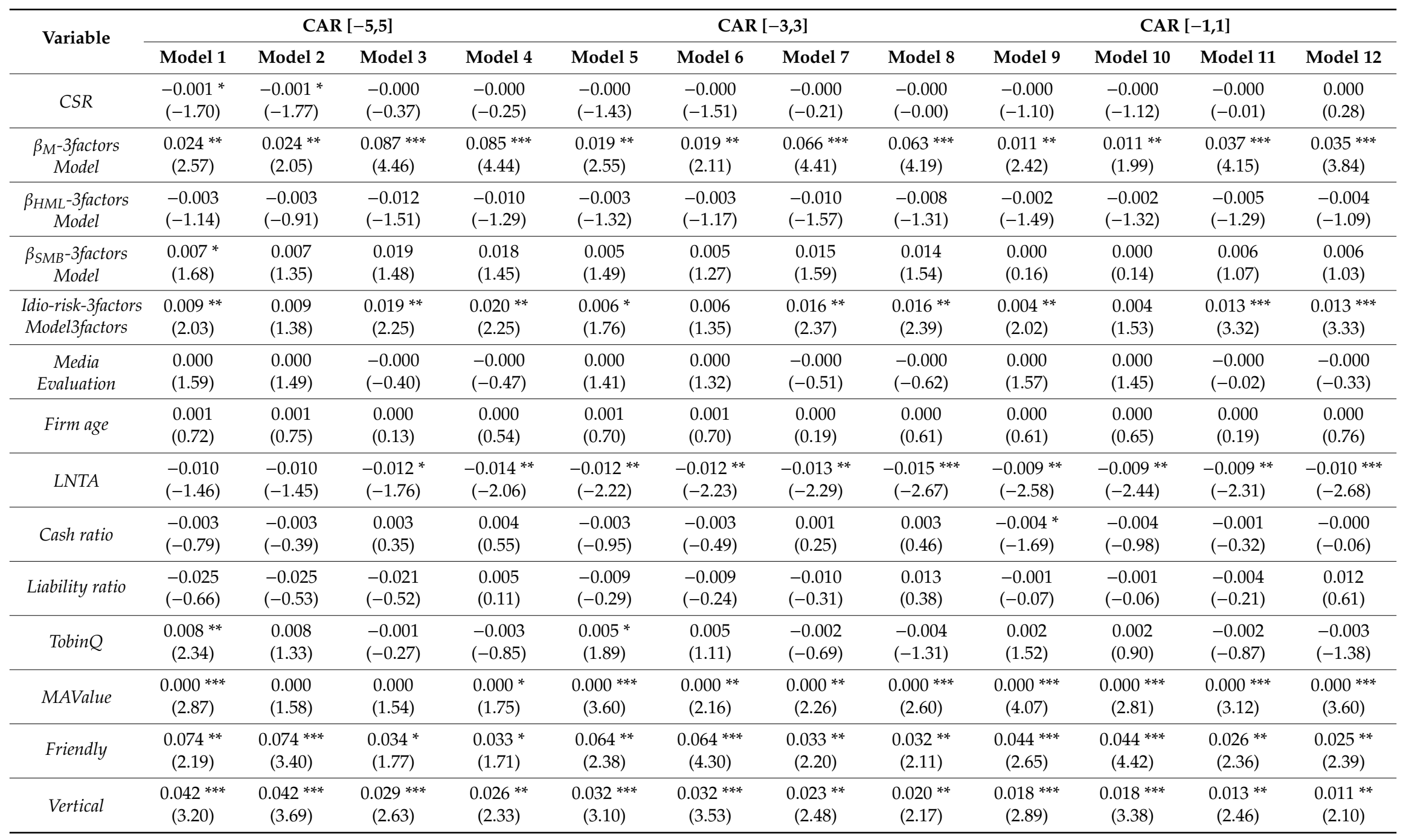


Table 5. Cont

\begin{tabular}{|c|c|c|c|c|c|c|c|c|c|c|c|c|}
\hline \multirow{2}{*}{ Variable } & \multicolumn{4}{|c|}{ CAR $[-5,5]$} & \multicolumn{4}{|c|}{ CAR $[-3,3]$} & \multicolumn{4}{|c|}{ CAR $[-1,1]$} \\
\hline & Model 1 & Model 2 & Model 3 & Model 4 & Model 5 & Model 6 & Model 7 & Model 8 & Model 9 & Model 10 & Model 11 & Model 12 \\
\hline Cons & $\begin{array}{c}-0.111 \text { ** } \\
(-2.27)\end{array}$ & $\begin{array}{c}-0.111^{* *} \\
(-2.49)\end{array}$ & $\begin{array}{c}-0.364^{* * *} \\
(-3.99)\end{array}$ & $\begin{array}{c}-0.267^{* * *} \\
(-3.53)\end{array}$ & $\begin{array}{c}-0.085^{* *} \\
(-2.15)\end{array}$ & $\begin{array}{c}-0.085^{* *} \\
(-2.37)\end{array}$ & $\begin{array}{c}-0.285^{* * *} \\
(-4.08)\end{array}$ & $\begin{array}{c}-0.214^{* * *} \\
(-3.57)\end{array}$ & $\begin{array}{c}-0.050 \text { ** } \\
(-2.06)\end{array}$ & $\begin{array}{c}-0.050 \text { ** } \\
(-2.28)\end{array}$ & $\begin{array}{c}-0.178^{* * *} \\
(-4.12)\end{array}$ & $\begin{array}{c}-0.142 * * * \\
(-3.77)\end{array}$ \\
\hline Year FE & No & No & Yes & Yes & No & No & Yes & Yes & No & No & Yes & Yes \\
\hline Industry FE & No & No & No & Yes & No & No & No & Yes & No & No & No & Yes \\
\hline Cluster & No & Yes & Yes & Yes & No & Yes & Yes & Yes & No & Yes & Yes & Yes \\
\hline N & 984 & 984 & 984 & 984 & 984 & 984 & 984 & 984 & 984 & 984 & 984 & 984 \\
\hline Adj. $R^{2}$ & 0.055 & 0.055 & 0.229 & 0.245 & 0.057 & 0.057 & 0.229 & 0.242 & 0.059 & 0.059 & 0.198 & 0.209 \\
\hline
\end{tabular}

Note: $t$-statistics in parentheses: ${ }^{*} p<0.1{ }^{* *} p<0.05$, *** $p<0.01$ 


\subsection{Robustness Test}

\subsubsection{Different CAR Methods}

Our main conclusion was obtained from the results of $C A R[-5,5], C A R[-3,3]$, and $C A R[-1,1]$. This conclusion may be affected by different methods of calculating CAR. Tables A3 and A4 show the empirical test results of $C A R[-2,2], C A R[-3,1]$, and $C A R[-2,1]$. From the results of Table A3, although the coefficients of CSR are significant at the 5\% significance level in model 5, model 6, model 9, and model 10, these results are not controlled by the year and industry fixed effects. When considering year and industry fixed effects, the impact of CSR on CAR is still not significant, as in model 4, model 8, and model 12. From the results of Table A4, CSR is not significant in all models, the conclusion shows that after considering the direct and indirect effects of CSR on CAR, the indirect effect of CSR on CAR is not significant. This result is consistent with Table 5 . Therefore, by performing CAR test for different robustness tests, we find the main conclusions of this paper remain valid.

\subsubsection{Fama-French Five-Factors Model}

Our main conclusions involved the calculation of the abnormal rate of return and the calculation of risk factors using the Fama-French three-factors model, so the conclusions may be influenced by the choice of model. Tables A5 and A6 provide the empirical results of the Fama-French five-factors model. From the results of Tables A5 and A6, CSR is not significant in most models. This result shows that the main conclusions of this paper remain valid.

\subsubsection{Difference Between State-Owned and Private Enterprises}

In this paper, we do not distinguish between state-owned and private enterprises in China, so the conclusion may be influenced by the type of enterprise. Tables A7-A9 provide the empirical results of state-owned enterprises and private enterprises. From the results in Table A7, although the coefficient of CSR is significant at the 5\% significance level in model 1, model 2, model 5, model 6, model 9, and model 10 with controlling the year and industry fixed effects, it is not significant in model 4, model 8, or model 12. The coefficient of CSR*SOE between CSR and state-owned enterprises is not significant. In Table A8, CSR is not significant for channel one and channel two in the channel effect variable, and has significant influence on channel three. In Table A9, the coefficients of CSR*SOE are not significant in all models. This conclusion shows that even considering the difference between state-owned enterprises and private enterprise CSR, the empirical results of this paper are still established.

\subsection{Discussion: Does CSR Help Corporate Mergers and Acquisitions?}

\subsubsection{Does CSR Affect the Premium of M\&A?}

Table 6 shows the effect of CSR on the M\&A premium. From the empirical results, the CSR and the media evaluation coefficients are not significant. This result suggests that the impact of the M\&A premium, either as a direct or indirect effect, is not significant. That is, the better the CSR level of the acquirer, there is no direct help to reduce the M\&A premium during the merger. This founding verifies the aforementioned hypothesis H3. 
Table 6. Impact of CSR on corporate merger and acquisition (M\&A) premium.

\begin{tabular}{|c|c|c|c|c|}
\hline & Premium1 & Premium2 & Premium1 & Premium2 \\
\hline variabie & Model 1 & Model 2 & Model 3 & Model 4 \\
\hline CSR & $\begin{array}{l}-0.016 \\
(-0.06)\end{array}$ & $\begin{array}{l}-0.039 \\
(-0.15)\end{array}$ & $\begin{array}{l}0.074 \\
(0.30)\end{array}$ & $\begin{array}{l}-0.075 \\
(-0.27)\end{array}$ \\
\hline$\beta_{M}$-3factors Model & & & $\begin{array}{c}-29.643 * \\
(-1.70)\end{array}$ & $\begin{array}{c}-46.692 * * \\
(-2.35)\end{array}$ \\
\hline$\beta_{H M L}-3$ factors Model & & & $\begin{array}{l}-8.595 \\
(-1.38)\end{array}$ & $\begin{array}{l}-6.341 \\
(-0.86)\end{array}$ \\
\hline$\beta_{S M B}-3$ factors Model & & & $\begin{array}{l}14.058 \\
(1.04)\end{array}$ & $\begin{array}{l}8.224 \\
(0.56)\end{array}$ \\
\hline $\begin{array}{l}\text { Idio-risk-3factors } \\
\text { Model3factors }\end{array}$ & & & $\begin{array}{c}-20.846^{* *} \\
(-2.27)\end{array}$ & $\begin{array}{c}-28.411^{* * * *} \\
(-2.86)\end{array}$ \\
\hline Media Evaluation & & & $\begin{array}{l}-0.080 \\
(-0.21)\end{array}$ & $\begin{array}{l}0.156 \\
(0.36)\end{array}$ \\
\hline Firm age & $\begin{array}{l}-1.836 \\
(-1.05)\end{array}$ & $\begin{array}{l}-1.594 \\
(-0.95)\end{array}$ & $\begin{array}{l}-0.768 \\
(-0.44)\end{array}$ & $\begin{array}{l}-0.818 \\
(-0.48)\end{array}$ \\
\hline LNTA & $\begin{array}{l}-3.111 \\
(-0.62)\end{array}$ & $\begin{array}{l}-3.226 \\
(-0.51)\end{array}$ & $\begin{array}{l}0.142 \\
(0.02)\end{array}$ & $\begin{array}{l}-0.344 \\
(-0.04)\end{array}$ \\
\hline Cash ratio & $\begin{array}{l}-1.143 \\
(-0.44)\end{array}$ & $\begin{array}{l}0.181 \\
(0.06)\end{array}$ & $\begin{array}{l}-2.405 \\
(-0.99)\end{array}$ & $\begin{array}{l}-0.902 \\
(-0.34)\end{array}$ \\
\hline Liability ratio & $\begin{array}{c}27.081 \\
(0.78)\end{array}$ & $\begin{array}{c}83.401 * \\
(1.84)\end{array}$ & $\begin{array}{c}29.500 \\
(0.92)\end{array}$ & $\begin{array}{c}90.239 * \\
(1.86)\end{array}$ \\
\hline Tobin $Q$ & $\begin{array}{l}0.804 \\
(0.30)\end{array}$ & $\begin{array}{l}2.432 \\
(0.82)\end{array}$ & $\begin{array}{l}2.270 \\
(0.45)\end{array}$ & $\begin{array}{l}4.193 \\
(0.75)\end{array}$ \\
\hline MAValue & $\begin{array}{l}-0.000 \\
(-0.26)\end{array}$ & $\begin{array}{l}0.005^{* * *} \\
(11.14)\end{array}$ & $\begin{array}{l}-0.000 \\
(-0.21)\end{array}$ & $\begin{array}{l}0.005^{* * *} \\
(16.97)\end{array}$ \\
\hline Friendly & $\begin{array}{l}27.924^{* * *} \\
(3.25)\end{array}$ & $\begin{array}{l}35.515^{* * *} \\
\quad(3.28)\end{array}$ & $\begin{array}{c}27.844^{* * *} \\
(3.14)\end{array}$ & $\begin{array}{l}37.166^{* * *} \\
(3.25)\end{array}$ \\
\hline Vertical & $\begin{array}{l}2.971 \\
(0.27)\end{array}$ & $\begin{array}{l}4.323 \\
(0.37)\end{array}$ & $\begin{array}{l}1.173 \\
(0.11)\end{array}$ & $\begin{array}{l}6.431 \\
(0.54)\end{array}$ \\
\hline Constant & $\begin{array}{l}-39.151 \\
(-1.16)\end{array}$ & $\begin{array}{c}-82.864^{* *} \\
(-2.38)\end{array}$ & $\begin{array}{c}155.352 * \\
(1.70)\end{array}$ & $\begin{array}{c}174.447^{*} \\
(1.82)\end{array}$ \\
\hline Year FE & Yes & Yes & Yes & Yes \\
\hline Industry FE & Yes & Yes & Yes & Yes \\
\hline Cluster & Yes & Yes & Yes & Yes \\
\hline N & 1188 & 1188 & 984 & 984 \\
\hline Adj. $R^{2}$ & 0.028 & 0.058 & 0.045 & 0.088 \\
\hline
\end{tabular}

Note: $t$-statistics in parentheses. ${ }^{*} p<0.1,{ }^{* *} p<0.05,{ }^{* * *} p<0.01$.

\subsubsection{Does CSR Affect Post-Merger Integration?}

Table 7 presents the impact of CSR on ROA difference 1, 2, 3, 4, and 5 after M\&A. Models 1, 2, 3,4 , and 5 demonstrate the test results of direct effects. Models 6, 7, 8, 9, and 10 highlight the direct and indirect effects. From the empirical results, CSR only impacts ROA changes in the year before and after M\&A, and has no significant effect on the average of ROA differences after two, three, four, or five years. 
Table 7. Impact of CSR on return on assets (ROA) before and after corporate mergers and acquisitions.

\begin{tabular}{|c|c|c|c|c|c|c|c|c|c|c|}
\hline \multirow{2}{*}{ Variable } & DROA1 & DROA2 & DROA3 & DROA4 & DROA5 & DROA1 & DROA2 & DROA3 & DROA4 & DROA5 \\
\hline & Model 1 & Model 2 & Model 3 & Model 4 & Model 5 & Model 6 & Model 7 & Model 8 & Model 9 & Model 10 \\
\hline CSR & $\begin{array}{c}-0.000 * * \\
(-1.99)\end{array}$ & $\begin{array}{l}-0.000 \\
(-0.68)\end{array}$ & $\begin{array}{l}0.000 \\
(0.48)\end{array}$ & $\begin{array}{l}0.000 \\
(0.39)\end{array}$ & $\begin{array}{l}-0.000 \\
(-0.90)\end{array}$ & $\begin{array}{l}-0.000 \\
(-1.16)\end{array}$ & $\begin{array}{l}-0.000 \\
(-0.19)\end{array}$ & $\begin{array}{l}0.000 \\
(0.89)\end{array}$ & $\begin{array}{l}0.000 \\
(0.78)\end{array}$ & $\begin{array}{l}0.000 \\
(0.05)\end{array}$ \\
\hline $\begin{array}{c}\beta_{M}-3 \text { factors } \\
\text { Model }\end{array}$ & & & & & & $\begin{array}{l}-0.001 \\
(-0.22)\end{array}$ & $\begin{array}{l}-0.004 \\
(-0.62)\end{array}$ & $\begin{array}{l}-0.005 \\
(-0.44)\end{array}$ & $\begin{array}{l}-0.032 * \\
(-1.66)\end{array}$ & $\begin{array}{c}-0.071^{* * *} \\
(-2.67)\end{array}$ \\
\hline $\begin{array}{c}\beta_{H M L}-3 \text { factors } \\
\text { Model }\end{array}$ & & & & & & $\begin{array}{l}0.005 \\
(1.07)\end{array}$ & $\begin{array}{l}0.006 \\
(1.56)\end{array}$ & $\begin{array}{l}0.001 \\
(0.23)\end{array}$ & $\begin{array}{l}0.000 \\
(0.07)\end{array}$ & $\begin{array}{l}-0.015 \\
(-1.49)\end{array}$ \\
\hline $\begin{array}{c}\beta_{S M B}-3 \text { factors } \\
\text { Model }\end{array}$ & & & & & & $\begin{array}{l}-0.010 \\
(-1.59)\end{array}$ & $\begin{array}{l}-0.009 * \\
(-1.75)\end{array}$ & $\begin{array}{l}-0.000 \\
(-0.04)\end{array}$ & $\begin{array}{l}-0.004 \\
(-0.64)\end{array}$ & $\begin{array}{l}-0.001 \\
(-0.09)\end{array}$ \\
\hline $\begin{array}{l}\text { Idio-risk-3factors } \\
\text { Model }\end{array}$ & & & & & & $\begin{array}{l}0.004 \\
(1.40)\end{array}$ & $\begin{array}{c}0.007^{*} \\
(1.77)\end{array}$ & $\begin{array}{l}0.006 \\
(1.23)\end{array}$ & $\begin{array}{l}0.002 \\
(0.21)\end{array}$ & $\begin{array}{l}0.002 \\
(0.15)\end{array}$ \\
\hline $\begin{array}{c}\text { Media } \\
\text { Evaluation }\end{array}$ & & & & & & $\begin{array}{l}-0.000 \\
(-0.91)\end{array}$ & $\begin{array}{l}-0.000 \\
(-0.57)\end{array}$ & $\begin{array}{l}-0.000 * \\
(-1.68)\end{array}$ & $\begin{array}{l}-0.000 * \\
(-1.96)\end{array}$ & $\begin{array}{l}0.000 \\
(0.28)\end{array}$ \\
\hline Firm age & $\begin{array}{l}0.000 \\
(1.00)\end{array}$ & $\begin{array}{l}0.001 * \\
(1.75)\end{array}$ & $\begin{array}{c}0.001 * * \\
(2.27)\end{array}$ & $\begin{array}{c}0.002 * * \\
(2.36)\end{array}$ & $\begin{array}{l}0.002 * \\
(1.70)\end{array}$ & $\begin{array}{l}0.000 \\
(0.05)\end{array}$ & $\begin{array}{l}0.001 \\
(1.40)\end{array}$ & $\begin{array}{c}0.001 * * \\
(2.16)\end{array}$ & $\begin{array}{c}0.002 * * \\
(2.24)\end{array}$ & $\begin{array}{l}0.002 \\
(1.44)\end{array}$ \\
\hline LNTA & $\begin{array}{c}-0.004 \text { * } \\
(-1.68)\end{array}$ & $\begin{array}{l}-0.004 \\
(-1.57) \\
\end{array}$ & $\begin{array}{c}-0.009 * * \\
(-2.57)\end{array}$ & $\begin{array}{c}-0.012^{* * *} \\
(-2.99)\end{array}$ & $\begin{array}{l}-0.001 \\
(-0.06)\end{array}$ & $\begin{array}{l}-0.006 \\
(-1.55)\end{array}$ & $\begin{array}{l}-0.004 \\
(-1.58)\end{array}$ & $\begin{array}{c}-0.008 \text { ** } \\
(-2.12)\end{array}$ & $\begin{array}{c}-0.012^{* * *} \\
(-2.86)\end{array}$ & $\begin{array}{l}-0.002 \\
(-0.16)\end{array}$ \\
\hline Cash ratio & $\begin{array}{l}0.003 \\
(0.88)\end{array}$ & $\begin{array}{l}0.000 \\
(0.26)\end{array}$ & $\begin{array}{l}0.001 \\
(0.29)\end{array}$ & $\begin{array}{l}-0.001 \\
(-0.36)\end{array}$ & $\begin{array}{l}-0.007 \\
(-0.86)\end{array}$ & $\begin{array}{l}0.003 \\
(0.83)\end{array}$ & $\begin{array}{l}-0.000 \\
(-0.23)\end{array}$ & $\begin{array}{l}0.000 \\
(0.16)\end{array}$ & $\begin{array}{l}-0.001 \\
(-0.28)\end{array}$ & $\begin{array}{l}-0.004 \\
(-0.58)\end{array}$ \\
\hline Liability ratio & $\begin{array}{c}0.042 \text { ** } \\
(2.56)\end{array}$ & $\begin{array}{c}0.036^{* *} \\
(2.52)\end{array}$ & $\begin{array}{c}0.062^{* * *} \\
(2.93)\end{array}$ & $\begin{array}{c}0.078 \text { ** } \\
(2.14)\end{array}$ & $\begin{array}{l}0.064 \\
(0.79)\end{array}$ & $\begin{array}{c}0.049 * * * \\
(2.69)\end{array}$ & $\begin{array}{c}0.042 \text { ** } \\
(2.54)\end{array}$ & $\begin{array}{c}0.059 * * * \\
(2.75)\end{array}$ & $\begin{array}{c}0.079 * * \\
(2.17)\end{array}$ & $\begin{array}{l}0.058 \\
(0.69)\end{array}$ \\
\hline Tobin $Q$ & $\begin{array}{l}0.001 \\
(0.77)\end{array}$ & $\begin{array}{c}0.003^{* *} \\
(2.05)\end{array}$ & $\begin{array}{l}0.002 \\
(1.25)\end{array}$ & $\begin{array}{l}-0.001 \\
(-0.21)\end{array}$ & $\begin{array}{l}0.003 \\
(0.34)\end{array}$ & $\begin{array}{l}0.001 \\
(0.52)\end{array}$ & $\begin{array}{c}0.005^{* * * *} \\
(2.90)\end{array}$ & $\begin{array}{l}0.002 \\
(1.19)\end{array}$ & $\begin{array}{l}-0.001 \\
(-0.33)\end{array}$ & $\begin{array}{l}0.002 \\
(0.18)\end{array}$ \\
\hline MAValue & $\begin{array}{l}0.000 \\
(1.22)\end{array}$ & $\begin{array}{l}0.000 \\
(1.15)\end{array}$ & $\begin{array}{l}0.000 \\
(1.22)\end{array}$ & $\begin{array}{c}0.000 * * * \\
(3.47)\end{array}$ & $\begin{array}{c}0.000 * * \\
(1.99)\end{array}$ & $\begin{array}{l}0.000 \\
(1.13)\end{array}$ & $\begin{array}{l}0.000 \\
(1.04)\end{array}$ & $\begin{array}{l}0.000 \\
(1.30)\end{array}$ & $\begin{array}{c}0.000^{* * * *} \\
(3.76)\end{array}$ & $\begin{array}{l}0.000 * \\
(1.70)\end{array}$ \\
\hline Friendly & $\begin{array}{l}0.010 \\
(1.16)\end{array}$ & $\begin{array}{c}0.028^{* * * *} \\
(2.69)\end{array}$ & $\begin{array}{c}0.032 * * \\
(2.37)\end{array}$ & $\begin{array}{l}0.020 \\
(1.30)\end{array}$ & $\begin{array}{l}0.020 \\
(0.99)\end{array}$ & $\begin{array}{l}0.008 \\
(0.98)\end{array}$ & $\begin{array}{c}0.026^{* * * *} \\
(2.72)\end{array}$ & $\begin{array}{c}0.031^{* *} \\
(2.37)\end{array}$ & $\begin{array}{l}0.018 \\
(1.30)\end{array}$ & $\begin{array}{l}0.014 \\
(0.72)\end{array}$ \\
\hline Vertical & $\begin{array}{l}0.006 \\
(1.41)\end{array}$ & $\begin{array}{l}0.007 \\
(1.56)\end{array}$ & $\begin{array}{l}0.008 \\
(1.42)\end{array}$ & $\begin{array}{l}0.002 \\
(0.32)\end{array}$ & $\begin{array}{l}0.005 \\
(0.47)\end{array}$ & $\begin{array}{l}0.005 \\
(1.01)\end{array}$ & $\begin{array}{l}0.006 \\
(1.35)\end{array}$ & $\begin{array}{l}0.009 \\
(1.59)\end{array}$ & $\begin{array}{l}0.003 \\
(0.55)\end{array}$ & $\begin{array}{l}0.008 \\
(0.87)\end{array}$ \\
\hline
\end{tabular}


Table 7. Cont

\begin{tabular}{|c|c|c|c|c|c|c|c|c|c|c|}
\hline \multirow{2}{*}{ Variable } & DROA1 & DROA2 & DROA3 & DROA4 & DROA5 & DROA1 & DROA2 & DROA3 & DROA4 & DROA5 \\
\hline & Model 1 & Model 2 & Model 3 & Model 4 & Model 5 & Model 6 & Model 7 & Model 8 & Model 9 & Model 10 \\
\hline Constant & $\begin{array}{c}-0.048 \text { ** } \\
(-2.58)\end{array}$ & $\begin{array}{c}-0.086^{* * *} \\
(-4.40)\end{array}$ & $\begin{array}{c}-0.092 * * * \\
(-3.49)\end{array}$ & $\begin{array}{c}-0.093^{* * *} \\
(-2.61)\end{array}$ & $\begin{array}{c}-0.126 * * \\
(-2.20)\end{array}$ & $\begin{array}{l}-0.023 \\
(-1.11)\end{array}$ & $\begin{array}{c}-0.153^{* * *} \\
(-3.44)\end{array}$ & $\begin{array}{c}-0.093 * * * \\
(-3.28)\end{array}$ & $\begin{array}{l}0.001 \\
(0.01)\end{array}$ & $\begin{array}{l}0.143 \\
(1.39)\end{array}$ \\
\hline Year FE & Yes & Yes & Yes & Yes & Yes & Yes & Yes & Yes & Yes & Yes \\
\hline Industry FE & Yes & Yes & Yes & Yes & Yes & Yes & Yes & Yes & Yes & Yes \\
\hline Cluster & Yes & Yes & Yes & Yes & Yes & Yes & Yes & Yes & Yes & Yes \\
\hline N & 1053 & 849 & 562 & 325 & 173 & 849 & 649 & 547 & 314 & 163 \\
\hline Adj. $R^{2}$ & 0.017 & 0.081 & 0.086 & 0.130 & 0.052 & 0.015 & 0.121 & 0.098 & 0.161 & 0.178 \\
\hline
\end{tabular}




\section{Conclusions and Implications}

Based on the empirical results, we found that the CSR level of the listed companies in the year prior to M\&A does not affect the market investors' judgment on the value of their mergers and acquisitions. Existing literature indicates that CSR could affect market investors' valuation by the acquiring company's systemic risks, idiosyncratic risks, and social public media. However, through empirical research, we found that these three channel effects do not exist in the Chinese market. Although the acquiring company's CSR affects the public opinion of their positive comments, the market investors do not value the influence of public opinion at the time of valuation and investors primarily focus on the commitment of M\&A companies to systemic risks and idiosyncratic risks. In terms of risk-taking, CSR affects neither systemic risks nor heterogeneity risks.

The reason why the market investors do not value the company's CSR is that they know that many Chinese companies' CSR behavior is characterized as passive CSR, affected by governments and regulatory institutions, instead of active CSR behavior undertaken for the company's long-term benefit. For this reason, CSR performance of an M\&A party does not help improve the market investors' evaluation of M\&A.

The policy implications of this article can come to several points. First, unlike developed countries, China is still a developing country. Because developed countries and developing countries are at different stages of development, policy makers have different requirements for corporate CSR. Our empirical results show that investors in the Chinese market are not paying much attention to the CSR of the acquirer. This is because most Chinese companies' CSR is passive CSR rather than active CSR. Passive CSR makes companies pay attention to CSR itself. While ignoring the true spirit of CSR, this passive behavior of adaptive rules has not improved the company's M\&A benefits. Therefore, in terms of policy supervision, policy makers should consider the passive CSR behavior of enterprises when revising the laws related to CSR.

Second, in addition to the differences in the development stage, the differences in geography, history, system, and culture between countries will also make the CSR between countries very different. Specifically, companies in North America pay more attention to strategy, charitable donations, and shareholder value when they engage in CSR. European companies pay more attention to environmental protection, and Japanese and Korean companies pay more attention to safe production. This difference makes companies focus on their own CSR performance. When adopting a non-uniform CSR standard, it is easy to get a conclusion that CSR and the acquirer CAR are not the same in different countries. Therefore, when we study the CSR behavior of companies in different countries, we must consider the different situations in the geographical, historical, institutional, and cultural characteristics of different countries.

In this study, we not distinguish between passive CSR behavior and active CSR behavior because of the limitations of the sample and method. If identifying whether the company's CSR is active or passive is possible, it might be of great help to study the impacts of CSR in further changing investors' evaluation at the time of M\&A by influencing the systemic risks and idiosyncratic risks. Due to the lack of global listed company information, we could not conduct a comparative analysis of CSR in different countries of the world. Data in these two areas would further improve the future identification of these transmission mechanisms and the study of passive CSR.

Author Contributions: M.L. wrote the article. F.Z. analyzed the data. F.L. performed the formal analysis.

Funding: This research was funded by the National Natural Science Foundation of China (grant no. 71603085), the China Postdoctoral Science Foundation (grant nos. 2016M600292 and 2017T100280), Fundamental Research Funds for the Central Universities (2017ECNU-YYJ026), and the Shanghai M\&A Financial Research Institute Science Foundation.

Conflicts of Interest: The authors declare no conflicts of interest. 


\section{Appendix A}

Table A1. Hexun Finance listed company social responsibility three-level evaluation system.

\begin{tabular}{|c|c|c|}
\hline First Level & Second Level & Third Level \\
\hline \multirow{9}{*}{$\begin{array}{l}\text { Shareholder } \\
\text { responsibility }(30 \%)\end{array}$} & \multirow[t]{2}{*}{ Earnings $(10 \%)$} & $\begin{array}{l}\text { Return on equity }(2 \%) \text {, return on assets }(2 \%) \text {, chief } \\
\text { return on assets }(2 \%) \text {, earnings per share }(2 \%)\end{array}$ \\
\hline & & $\begin{array}{l}\text { Return on cost and expense }(1 \%) \text {, undistributed } \\
\text { profit per share }(1 \%)\end{array}$ \\
\hline & \multirow{2}{*}{ Debt paying $(3 \%)$} & Debt ratio $(1 \%)$ \\
\hline & & $\begin{array}{l}\text { Quick ratio }(0.5 \%) \text {, current ratio }(0.5 \%) \\
\text { cash ratio }(0.5 \%) \text {, equity ratio }(0.5 \%)\end{array}$ \\
\hline & \multirow{2}{*}{ Returns ( $8 \%)$} & Dividend yield ratio $(3 \%)$, dividend share $(3 \%)$ \\
\hline & & Dividend financing ratio $(2 \%)$ \\
\hline & Information disclosure (5\%) & $\begin{array}{l}\text { Number of penalties imposed by the exchange on } \\
\text { companies and related responsible persons (5\%) }\end{array}$ \\
\hline & \multirow{2}{*}{ Innovation $(4 \%)$} & Number of technical innovation projects $(2 \%)$ \\
\hline & & $\begin{array}{l}\text { Expenditure on product development }(1 \%) \text {, concept } \\
\text { of technical innovation }(1 \%)\end{array}$ \\
\hline \multirow{6}{*}{$\begin{array}{l}\text { Employee } \\
\text { responsibility }(15 \%)\end{array}$} & \multirow{2}{*}{ Performance $(5 \%)$} & Per capita income of employees ( $4 \%)$ \\
\hline & & Staff training $(1 \%)$ \\
\hline & \multirow{4}{*}{ Caring for employees ( $5 \%)$} & Safety training $(3 \%)$ \\
\hline & & Safety check $(2 \%)$ \\
\hline & & Consoling employees $(2 \%)$, consolation money $(2 \%)$ \\
\hline & & Consolation consciousness ( $1 \%)$ \\
\hline \multirow{5}{*}{$\begin{array}{l}\text { Supplier customer } \\
\text { and customer } \\
\text { responsibility }(15 \%)\end{array}$} & \multirow{2}{*}{ Product quality $(7 \%)$} & Quality management system certificate (4\%) \\
\hline & & Quality management awareness (3\%) \\
\hline & After-sales service $(3 \%)$ & Customer satisfaction survey ( $3 \%)$ \\
\hline & Integrity and reciprocity (5\%) & Fair competition among suppliers (3\%) \\
\hline & & Anti-commercial bribery training $(2 \%)$ \\
\hline $\begin{array}{l}\text { Environmental } \\
\text { responsibility (20\%) }\end{array}$ & $\begin{array}{c}\text { Environmental } \\
\text { governance }(20 \%)\end{array}$ & $\begin{array}{l}\text { Amount of environmental protection input }(5 \%) \\
\text { Number of pollutant discharge types }(5 \%) \\
\text { Number of energy saving types }(5 \%)\end{array}$ \\
\hline & & Environmental management system certification (3\%) \\
\hline & & Environmental awareness (2\%) \\
\hline Social & Contributed value $(20 \%)$ & Income tax as a percentage of total profit $(10 \%)$ \\
\hline responsibility (20\%) & & Amount of public welfare donation $(10 \%)$ \\
\hline
\end{tabular}


Table A2. Key variables, source, and definitions.

\begin{tabular}{|c|c|c|}
\hline Variable & Source & Definition \\
\hline CAR $[-1,1]$ & Calculated by Equation (3) & CAR a day before and after announcement day \\
\hline CAR $[-2,2]$ & Calculated by Equation (3) & CAR two days before and after announcement day \\
\hline$C A R[-3,3]$ & Calculated by Equation (3) & CAR three days before and after announcement day \\
\hline CAR $[-5,5]$ & Calculated by Equation (3) & CAR five days before and after announcement day \\
\hline$C A R[-2,1]$ & Calculated by Equation (3) & CAR two days before and one day after announcement day \\
\hline CAR $[-3,1]$ & Calculated by Equation (3) & CAR three days before and one day after announcement day \\
\hline CSR & Hexun Finance Website & $\begin{array}{l}\text { The average of net scores of Hexun Measures on five dimensions include } \\
\text { shareholder responsibility, employee responsibility, supplier customer and } \\
\text { customer responsibility, environmental responsibility, social responsibility }\end{array}$ \\
\hline $\begin{array}{l}\text { Media } \\
\text { Evaluation }\end{array}$ & Calculated by formula (1) & $\begin{array}{c}\text { (Positive report frequency - negative report frequency)/(1+ positive report } \\
\text { frequency + negative report frequency) }\end{array}$ \\
\hline $\begin{array}{l}\beta_{M-3 f a c t o r s} \\
\text { Model }\end{array}$ & CSMAR & $\begin{array}{l}\text { Beta coefficient of the market risk premium of the Fama-French } \\
\text { three-factors model using daily stock returns of previous } 12 \text { months }\end{array}$ \\
\hline $\begin{array}{l}\beta_{\text {HML }}-3 \text { factors } \\
\text { Model }\end{array}$ & CSMAR & $\begin{array}{l}\text { Beta coefficient of the size risk premium of the Fama-French three-factors } \\
\text { model using daily stock returns of previous } 12 \text { months }\end{array}$ \\
\hline $\begin{array}{l}\beta_{S M B}-3 \text { factors } \\
\text { Model }\end{array}$ & CSMAR & $\begin{array}{l}\text { Beta coefficient of the BM risk premium of the Fama-French three-factors } \\
\text { model using daily stock returns of previous } 12 \text { months }\end{array}$ \\
\hline $\begin{array}{l}\text { Idio-risk-3factors } \\
\text { Model }\end{array}$ & CSMAR & $\begin{array}{l}\text { Residual variance of the Fama-French three-factors model using daily stock } \\
\text { returns of the previous } 12 \text { months }\end{array}$ \\
\hline Firm Size & CSMAR & Natural logarithm of Total Assets \\
\hline Liability ratio & CSMAR & Liabilities/Total Assets \\
\hline Cash Ratio & CSMAR & Cash and Cash Equivalents/Current Assets \\
\hline Tobin $Q$ & CSMAR & Market Value/Total Assets \\
\hline Firm Age & Wind & Year of the transaction-established year \\
\hline MA Value & CSMAR & Deal Price of Acquisition \\
\hline Friendly & SDC & $\begin{array}{l}\text { Dummy variable equals one if the merger is a malicious acquisition, and } \\
\text { zero if otherwise }\end{array}$ \\
\hline Vertical & SDC & $\begin{array}{l}\text { Dummy variable equals one if the merger is a vertical acquisition, and zero } \\
\text { if otherwise }\end{array}$ \\
\hline $\begin{array}{l}\beta_{M-5 f a c t o r s} \\
\quad \text { Model }\end{array}$ & CSMAR & $\begin{array}{l}\text { Beta coefficient of the market risk premium of the Fama-French five-factors } \\
\text { model using daily stock returns of previous } 12 \text { months }\end{array}$ \\
\hline $\begin{array}{l}\beta_{H M L}-5 \text { factors } \\
\text { Model }\end{array}$ & CSMAR & $\begin{array}{l}\text { Beta coefficient of the size risk premium of the Fama-French five-factors } \\
\text { model using daily stock returns of previous } 12 \text { months }\end{array}$ \\
\hline $\begin{array}{l}\beta_{S M B}-5 \text { factors } \\
\text { Model }\end{array}$ & CSMAR & $\begin{array}{l}\text { Beta coefficient of the BM risk premium of the Fama-French five-factors } \\
\text { model using daily stock returns of previous } 12 \text { months }\end{array}$ \\
\hline $\begin{array}{l}\beta_{R M W}-5 \text { factors } \\
\text { Model }\end{array}$ & CSMAR & $\begin{array}{l}\text { Beta coefficient of the RMW risk premium of the Fama-French five-factors } \\
\text { model using daily stock returns of previous } 12 \text { months }\end{array}$ \\
\hline $\begin{array}{l}\beta_{C M A}-5 \text { factors } \\
\quad \text { Model }\end{array}$ & CSMAR & $\begin{array}{l}\text { Beta coefficient of the CMA risk premium of the Fama-French five-factors } \\
\text { model using daily stock returns of previous } 12 \text { months }\end{array}$ \\
\hline $\begin{array}{l}\text { Idio-risk-5factors } \\
\quad \text { Model }\end{array}$ & CSMAR & $\begin{array}{l}\text { Residual variance of the Fama-French five-factors model using daily stock } \\
\text { returns of the previous } 12 \text { months }\end{array}$ \\
\hline MAPremium1 & CSMAR & (Expense Value - Underlying Value)/Underlying Value $\times 100 \%$ \\
\hline MAPremium 2 & CSMAR & $\begin{array}{c}\text { (Cash Amount }+ \text { Debt Amount }+ \text { Equity Amount-Underlying } \\
\text { Value }) / \text { Underlying Value } \times 100 \%\end{array}$ \\
\hline DROA1 & CSMAR & ROA one year after the M\&A transaction to one year before \\
\hline DROA2 & CSMAR & Average ROA two years after the M\&A transaction to two years before \\
\hline DROA3 & CSMAR & Average ROA three years after the M\&A transaction to three years before \\
\hline DROA4 & CSMAR & Average ROA four years after the M\&A transaction to four years before \\
\hline DROA5 & CSMAR & Average ROA five years after the M\&A transaction to five years before \\
\hline
\end{tabular}


Table A3. Robustness test 1: different CAR indicators.

\begin{tabular}{|c|c|c|c|c|c|c|c|c|c|c|c|c|}
\hline \multirow{2}{*}{ Variable } & \multicolumn{4}{|c|}{ CAR $[-2,2]$} & \multicolumn{4}{|c|}{ CAR $[-3,1]$} & \multicolumn{4}{|c|}{ CAR [-2,1] } \\
\hline & Model 1 & Model 2 & Model 3 & Model 4 & Model 5 & Model 6 & Model 7 & Model 8 & Model 9 & Model 10 & Model 11 & Model 12 \\
\hline CSR & $\begin{array}{l}-0.000 \\
(-1.34) \\
\end{array}$ & $\begin{array}{l}-0.000 \\
(-1.44)\end{array}$ & $\begin{array}{l}-0.000 \\
(-0.83)\end{array}$ & $\begin{array}{l}-0.000 \\
(-0.43)\end{array}$ & $\begin{array}{c}-0.000 * \\
(-1.91)\end{array}$ & $\begin{array}{c}-0.000 * \\
(-1.90)\end{array}$ & $\begin{array}{l}-0.000 \\
(-1.16) \\
\end{array}$ & $\begin{array}{l}-0.000 \\
(-0.86)\end{array}$ & $\begin{array}{c}-0.000 * \\
(-1.91)\end{array}$ & $\begin{array}{c}-0.000 * \\
(-1.90)\end{array}$ & $\begin{array}{l}-0.000 \\
(-1.16)\end{array}$ & $\begin{array}{l}-0.000 \\
(-0.86)\end{array}$ \\
\hline Firm age & $\begin{array}{l}0.000 \\
(0.46)\end{array}$ & $\begin{array}{l}0.000 \\
(0.46)\end{array}$ & $\begin{array}{l}0.000 \\
(0.22)\end{array}$ & $\begin{array}{l}0.001 \\
(1.08)\end{array}$ & $\begin{array}{l}0.000 \\
(0.31)\end{array}$ & $\begin{array}{l}0.000 \\
(0.33)\end{array}$ & $\begin{array}{l}-0.000 \\
(-0.22)\end{array}$ & $\begin{array}{l}0.000 \\
(0.52)\end{array}$ & $\begin{array}{l}0.000 \\
(0.31)\end{array}$ & $\begin{array}{l}0.000 \\
(0.33)\end{array}$ & $\begin{array}{l}-0.000 \\
(-0.22)\end{array}$ & $\begin{array}{l}0.000 \\
(0.52)\end{array}$ \\
\hline LNTA & $\begin{array}{c}-0.007 * \\
(-1.74)\end{array}$ & $\begin{array}{c}-0.007 * \\
(-1.70)\end{array}$ & $\begin{array}{c}-0.009 * * \\
(-2.08)\end{array}$ & $\begin{array}{c}-0.011^{* *} \\
(-2.42)\end{array}$ & $\begin{array}{c}-0.005 \text { *** } \\
(-2.82)\end{array}$ & $\begin{array}{c}-0.005^{* * *} \\
(-2.72)\end{array}$ & $\begin{array}{c}-0.006^{* * *} \\
(-3.29)\end{array}$ & $\begin{array}{c}-0.007^{* * *} \\
(-3.97)\end{array}$ & $\begin{array}{c}-0.005^{* * *} \\
(-2.82)\end{array}$ & $\begin{array}{c}-0.005^{* * *} \\
(-2.72)\end{array}$ & $\begin{array}{c}-0.006^{* * *} \\
(-3.29)\end{array}$ & $\begin{array}{c}-0.007^{* * *} \\
(-3.97)\end{array}$ \\
\hline Cash ratio & $\begin{array}{l}-0.003 \\
(-1.09)\end{array}$ & $\begin{array}{l}-0.003 \\
(-0.61) \\
\end{array}$ & $\begin{array}{l}-0.001 \\
(-0.22)\end{array}$ & $\begin{array}{l}0.000 \\
(0.05)\end{array}$ & $\begin{array}{l}-0.002 \\
(-1.58)\end{array}$ & $\begin{array}{l}-0.002 \\
(-1.02)\end{array}$ & $\begin{array}{l}-0.001 \\
(-0.43)\end{array}$ & $\begin{array}{l}-0.000 \\
(-0.13)\end{array}$ & $\begin{array}{l}-0.002 \\
(-1.58)\end{array}$ & $\begin{array}{l}-0.002 \\
(-1.02)\end{array}$ & $\begin{array}{l}-0.001 \\
(-0.43)\end{array}$ & $\begin{array}{l}-0.000 \\
(-0.13)\end{array}$ \\
\hline $\begin{array}{c}\text { Liability } \\
\text { ratio }\end{array}$ & $\begin{array}{l}-0.003 \\
(-0.13)\end{array}$ & $\begin{array}{l}-0.003 \\
(-0.10) \\
\end{array}$ & $\begin{array}{l}-0.003 \\
(-0.10) \\
\end{array}$ & $\begin{array}{l}0.010 \\
(0.36)\end{array}$ & $\begin{array}{l}0.007 \\
(0.70) \\
\end{array}$ & $\begin{array}{l}0.007 \\
(0.65) \\
\end{array}$ & $\begin{array}{l}0.009 \\
(0.91) \\
\end{array}$ & $\begin{array}{l}0.014 \\
(1.48) \\
\end{array}$ & $\begin{array}{l}0.007 \\
(0.70) \\
\end{array}$ & $\begin{array}{l}0.007 \\
(0.65) \\
\end{array}$ & $\begin{array}{l}0.009 \\
(0.91) \\
\end{array}$ & $\begin{array}{l}0.014 \\
(1.48) \\
\end{array}$ \\
\hline Tobin $Q$ & $\begin{array}{c}0.005^{* * *} \\
(2.81)\end{array}$ & $\begin{array}{c}0.005^{*} \\
(1.74)\end{array}$ & $\begin{array}{l}0.001 \\
(0.43)\end{array}$ & $\begin{array}{l}0.000 \\
(0.00)\end{array}$ & $\begin{array}{c}0.001^{* *} \\
(2.03)\end{array}$ & $\begin{array}{l}0.001 \\
(1.49)\end{array}$ & $\begin{array}{l}-0.000 \\
(-0.20)\end{array}$ & $\begin{array}{l}-0.001 \\
(-0.59) \\
\end{array}$ & $\begin{array}{c}0.001^{* *} \\
(2.03)\end{array}$ & $\begin{array}{l}0.001 \\
(1.49)\end{array}$ & $\begin{array}{l}-0.000 \\
(-0.20)\end{array}$ & $\begin{array}{l}-0.001 \\
(-0.59) \\
\end{array}$ \\
\hline MAValue & $\begin{array}{c}0.000^{* * *} \\
(4.12)\end{array}$ & $\begin{array}{c}0.000^{* *} \\
(2.17)\end{array}$ & $\begin{array}{c}0.000 * * \\
(2.17)\end{array}$ & $\begin{array}{c}0.000 * * \\
(2.31)\end{array}$ & $\begin{array}{c}0.000 * * * \\
(3.85)\end{array}$ & $\begin{array}{c}0.000^{* *} \\
(2.22)\end{array}$ & $\begin{array}{c}0.000^{* *} \\
(2.21)\end{array}$ & $\begin{array}{c}0.000 * * \\
(2.39)\end{array}$ & $\begin{array}{c}0.000 * * * \\
(3.85)\end{array}$ & $\begin{array}{c}0.000 * * \\
(2.22)\end{array}$ & $\begin{array}{c}0.000^{* *} \\
(2.21)\end{array}$ & $\begin{array}{c}0.000 \text { ** } \\
(2.39)\end{array}$ \\
\hline Friendly & $\begin{array}{c}0.051^{* *} \\
(2.28)\end{array}$ & $\begin{array}{c}0.051^{* * *} \\
(4.57)\end{array}$ & $\begin{array}{c}0.033^{* * *} \\
(2.76)\end{array}$ & $\begin{array}{c}0.032^{* * *} \\
(2.71)\end{array}$ & $\begin{array}{c}0.023^{* *} \\
(2.57)\end{array}$ & $\begin{array}{c}0.023^{* * * *} \\
(4.24)\end{array}$ & $\begin{array}{c}0.014^{* *} \\
(2.25)\end{array}$ & $\begin{array}{c}0.014^{* *} \\
(2.16)\end{array}$ & $\begin{array}{c}0.023^{* *} \\
(2.57)\end{array}$ & $\begin{array}{c}0.023^{* * *} \\
(4.24)\end{array}$ & $\begin{array}{c}0.014^{* *} \\
(2.25)\end{array}$ & $\begin{array}{c}0.014^{* *} \\
(2.16)\end{array}$ \\
\hline Vertical & $\begin{array}{c}0.022^{* * *} \\
(2.78)\end{array}$ & $\begin{array}{c}0.022^{* * *} \\
(3.26)\end{array}$ & $\begin{array}{c}0.018^{* * * *} \\
(2.65)\end{array}$ & $\begin{array}{c}0.017^{* *} \\
(2.45)\end{array}$ & $\begin{array}{l}0.004 \\
(1.33)\end{array}$ & $\begin{array}{l}0.004 \\
(1.50)\end{array}$ & $\begin{array}{l}0.002 \\
(0.71)\end{array}$ & $\begin{array}{l}0.002 \\
(0.60)\end{array}$ & $\begin{array}{l}0.004 \\
(1.33)\end{array}$ & $\begin{array}{l}0.004 \\
(1.50)\end{array}$ & $\begin{array}{l}0.002 \\
(0.71)\end{array}$ & $\begin{array}{l}0.002 \\
(0.60)\end{array}$ \\
\hline Constant & $\begin{array}{l}-0.022 \\
(-0.78)\end{array}$ & $\begin{array}{l}-0.022 \\
(-1.02)\end{array}$ & $\begin{array}{l}-0.024 \\
(-1.11) \\
\end{array}$ & $\begin{array}{c}-0.054 \text { * } \\
(-1.96)\end{array}$ & $\begin{array}{l}-0.002 \\
(-0.17)\end{array}$ & $\begin{array}{l}-0.002 \\
(-0.22)\end{array}$ & $\begin{array}{l}-0.004 \\
(-0.47)\end{array}$ & $\begin{array}{l}-0.011 \\
(-1.00)\end{array}$ & $\begin{array}{l}-0.002 \\
(-0.17)\end{array}$ & $\begin{array}{l}-0.002 \\
(-0.22)\end{array}$ & $\begin{array}{l}-0.004 \\
(-0.47)\end{array}$ & $\begin{array}{l}-0.011 \\
(-1.00)\end{array}$ \\
\hline Year FE & No & No & Yes & Yes & No & No & Yes & Yes & No & No & Yes & Yes \\
\hline $\begin{array}{c}\text { Industry } \\
F E\end{array}$ & No & No & No & Yes & No & No & No & Yes & No & No & No & Yes \\
\hline Cluster & No & Yes & Yes & Yes & No & Yes & Yes & Yes & No & Yes & Yes & Yes \\
\hline$N$ & 1188 & 1188 & 1188 & 1188 & 1188 & 1188 & 1188 & 1188 & 1188 & 1188 & 1188 & 1188 \\
\hline $\operatorname{Adj} R^{2}$ & 0.042 & 0.042 & 0.107 & 0.121 & 0.040 & 0.040 & 0.118 & 0.127 & 0.040 & 0.040 & 0.118 & 0.127 \\
\hline
\end{tabular}


Table A4. Robustness test 1: different CAR indicators.

\begin{tabular}{|c|c|c|c|c|c|c|c|c|c|c|c|c|}
\hline \multirow{2}{*}{ Variable } & \multicolumn{4}{|c|}{ CAR $[-2,2]$} & \multicolumn{4}{|c|}{ CAR $[-3,1]$} & \multicolumn{4}{|c|}{ CAR $[-2,1]$} \\
\hline & Model 1 & Model 2 & Model 3 & Model 4 & Model 5 & Model 6 & Model 7 & Model 8 & Model 9 & Model 10 & Model 11 & Model 12 \\
\hline CSR & $\begin{array}{l}-0.000 \\
(-1.05)\end{array}$ & $\begin{array}{l}-0.000 \\
(-1.09)\end{array}$ & $\begin{array}{l}0.000 \\
(0.19)\end{array}$ & $\begin{array}{l}0.000 \\
(0.45)\end{array}$ & $\begin{array}{l}-0.000 \\
(-1.55)\end{array}$ & $\begin{array}{l}-0.000 \\
(-1.50)\end{array}$ & $\begin{array}{l}-0.000 \\
(-0.68)\end{array}$ & $\begin{array}{l}-0.000 \\
(-0.51)\end{array}$ & $\begin{array}{l}-0.000 \\
(-1.55)\end{array}$ & $\begin{array}{l}-0.000 \\
(-1.50)\end{array}$ & $\begin{array}{l}-0.000 \\
(-0.68)\end{array}$ & $\begin{array}{l}-0.000 \\
(-0.51)\end{array}$ \\
\hline $\begin{array}{c}\beta_{M^{-3 f a c t o r s}} \\
\text { Model }\end{array}$ & $\begin{array}{c}0.014^{* *} \\
(2.31)\end{array}$ & $\begin{array}{c}0.014^{*} \\
(1.90)\end{array}$ & $\begin{array}{c}0.052^{* * *} \\
(4.28)\end{array}$ & $\begin{array}{c}0.049^{* * *} \\
(4.05)\end{array}$ & $\begin{array}{l}0.004 \\
(1.43)\end{array}$ & $\begin{array}{l}0.004 \\
(1.25)\end{array}$ & $\begin{array}{c}0.014^{* * *} \\
(3.04)\end{array}$ & $\begin{array}{c}0.013^{* * *} \\
(2.62)\end{array}$ & $\begin{array}{l}0.004 \\
(1.43)\end{array}$ & $\begin{array}{l}0.004 \\
(1.25)\end{array}$ & $\begin{array}{c}0.014 * * * \\
(3.04)\end{array}$ & $\begin{array}{c}0.013 * * * \\
(2.62)\end{array}$ \\
\hline $\begin{array}{c}\beta_{H M L}-3 \text { factors } \\
\text { Model }\end{array}$ & $\begin{array}{l}-0.002 \\
(-1.24) \\
\end{array}$ & $\begin{array}{l}-0.002 \\
(-1.10) \\
\end{array}$ & $\begin{array}{l}-0.005 \\
(-1.05) \\
\end{array}$ & $\begin{array}{l}-0.004 \\
(-0.87) \\
\end{array}$ & $\begin{array}{l}-0.001 \\
(-1.32) \\
\end{array}$ & $\begin{array}{l}-0.001 \\
(-1.35) \\
\end{array}$ & $\begin{array}{l}-0.002 \\
(-1.14) \\
\end{array}$ & $\begin{array}{l}-0.002 \\
(-0.97) \\
\end{array}$ & $\begin{array}{l}-0.001 \\
(-1.32) \\
\end{array}$ & $\begin{array}{l}-0.001 \\
(-1.35) \\
\end{array}$ & $\begin{array}{l}-0.002 \\
(-1.14) \\
\end{array}$ & $\begin{array}{l}-0.002 \\
(-0.97) \\
\end{array}$ \\
\hline $\begin{array}{c}\beta_{S M B}-3 \text { factors } \\
\text { Model }\end{array}$ & $\begin{array}{l}0.002 \\
(0.86)\end{array}$ & $\begin{array}{l}0.002 \\
(0.73)\end{array}$ & $\begin{array}{l}0.008 \\
(1.05)\end{array}$ & $\begin{array}{l}0.008 \\
(1.05)\end{array}$ & $\begin{array}{l}-0.000 \\
(-0.46)\end{array}$ & $\begin{array}{l}-0.000 \\
(-0.44) \\
\end{array}$ & $\begin{array}{l}0.003 \\
(0.91)\end{array}$ & $\begin{array}{l}0.003 \\
(0.89)\end{array}$ & $\begin{array}{l}-0.000 \\
(-0.46)\end{array}$ & $\begin{array}{l}-0.000 \\
(-0.44)\end{array}$ & $\begin{array}{l}0.003 \\
(0.91)\end{array}$ & $\begin{array}{l}0.003 \\
(0.89)\end{array}$ \\
\hline $\begin{array}{c}\text { Idio-risk-3factors } \\
\text { Model3factors }\end{array}$ & $\begin{array}{c}0.005^{*} \\
(1.78)\end{array}$ & $\begin{array}{l}0.005 \\
(1.36)\end{array}$ & $\begin{array}{c}0.015^{* * *} \\
(2.87)\end{array}$ & $\begin{array}{c}0.016^{* * *} \\
(2.84)\end{array}$ & $\begin{array}{l}0.002 \\
(1.63)\end{array}$ & $\begin{array}{l}0.002 \\
(1.47)\end{array}$ & $\begin{array}{c}0.005^{* *} \\
(2.55)\end{array}$ & $\begin{array}{c}0.006^{* * *} \\
(2.63)\end{array}$ & $\begin{array}{l}0.002 \\
(1.63)\end{array}$ & $\begin{array}{l}0.002 \\
(1.47)\end{array}$ & $\begin{array}{c}0.005^{* *} \\
(2.55)\end{array}$ & $\begin{array}{c}0.006^{* * *} \\
(2.63)\end{array}$ \\
\hline $\begin{array}{c}\text { Media } \\
\text { Evaluation }\end{array}$ & $\begin{array}{l}0.000 \\
(1.64) \\
\end{array}$ & $\begin{array}{l}0.000 \\
(1.54) \\
\end{array}$ & $\begin{array}{l}-0.000 \\
(-0.09)\end{array}$ & $\begin{array}{l}-0.000 \\
(-0.29)\end{array}$ & $\begin{array}{l}0.000 \\
(1.32)\end{array}$ & $\begin{array}{l}0.000 \\
(1.24)\end{array}$ & $\begin{array}{l}-0.000 \\
(-0.14) \\
\end{array}$ & $\begin{array}{l}-0.000 \\
(-0.17)\end{array}$ & $\begin{array}{l}0.000 \\
(1.32)\end{array}$ & $\begin{array}{l}0.000 \\
(1.24)\end{array}$ & $\begin{array}{l}-0.000 \\
(-0.14)\end{array}$ & $\begin{array}{l}-0.000 \\
(-0.17)\end{array}$ \\
\hline Firm age & $\begin{array}{l}0.001 \\
(0.98)\end{array}$ & $\begin{array}{l}0.001 \\
(1.05)\end{array}$ & $\begin{array}{l}0.000 \\
(0.50)\end{array}$ & $\begin{array}{l}0.001 \\
(0.97)\end{array}$ & $\begin{array}{l}0.000 \\
(0.87)\end{array}$ & $\begin{array}{l}0.000 \\
(1.03)\end{array}$ & $\begin{array}{l}0.000 \\
(0.54)\end{array}$ & $\begin{array}{l}0.000 \\
(0.89)\end{array}$ & $\begin{array}{l}0.000 \\
(0.87)\end{array}$ & $\begin{array}{l}0.000 \\
(1.03)\end{array}$ & $\begin{array}{l}0.000 \\
(0.54)\end{array}$ & $\begin{array}{l}0.000 \\
(0.89)\end{array}$ \\
\hline LNTA & $\begin{array}{c}-0.010 * * \\
(-2.16)\end{array}$ & $\begin{array}{c}-0.010^{* *} \\
(-2.13)\end{array}$ & $\begin{array}{c}-0.011 \text { ** } \\
(-2.27)\end{array}$ & $\begin{array}{c}-0.012 \text { ** } \\
(-2.50)\end{array}$ & $\begin{array}{c}-0.006^{* * *} \\
(-3.44)\end{array}$ & $\begin{array}{c}-0.006^{* * * *} \\
(-3.29)\end{array}$ & $\begin{array}{c}-0.006^{* * * *} \\
(-2.91)\end{array}$ & $\begin{array}{c}-0.007^{* * *} \\
(-3.50)\end{array}$ & $\begin{array}{c}-0.006^{* * *} \\
(-3.44)\end{array}$ & $\begin{array}{c}-0.006^{* * *} \\
(-3.29)\end{array}$ & $\begin{array}{c}-0.006^{* * *} \\
(-2.91)\end{array}$ & $\begin{array}{r}-0.007^{* *} \\
(-3.50)\end{array}$ \\
\hline Cash ratio & $\begin{array}{l}-0.003 \\
(-1.09)\end{array}$ & $\begin{array}{l}-0.003 \\
(-0.59)\end{array}$ & $\begin{array}{l}0.001 \\
(0.13)\end{array}$ & $\begin{array}{l}0.002 \\
(0.38)\end{array}$ & $\begin{array}{l}-0.002 \\
(-1.51)\end{array}$ & $\begin{array}{l}-0.002 \\
(-0.97)\end{array}$ & $\begin{array}{l}-0.001 \\
(-0.32)\end{array}$ & $\begin{array}{l}-0.000 \\
(-0.12)\end{array}$ & $\begin{array}{l}-0.002 \\
(-1.51)\end{array}$ & $\begin{array}{l}-0.002 \\
(-0.97)\end{array}$ & $\begin{array}{l}-0.001 \\
(-0.32)\end{array}$ & $\begin{array}{l}-0.000 \\
(-0.12)\end{array}$ \\
\hline Liability ratio & $\begin{array}{l}-0.008 \\
(-0.31)\end{array}$ & $\begin{array}{l}-0.008 \\
(-0.25)\end{array}$ & $\begin{array}{l}-0.009 \\
(-0.34)\end{array}$ & $\begin{array}{l}0.007 \\
(0.26)\end{array}$ & $\begin{array}{l}0.005 \\
(0.47)\end{array}$ & $\begin{array}{l}0.005 \\
(0.44)\end{array}$ & $\begin{array}{l}0.003 \\
(0.27)\end{array}$ & $\begin{array}{l}0.008 \\
(0.73)\end{array}$ & $\begin{array}{l}0.005 \\
(0.47)\end{array}$ & $\begin{array}{l}0.005 \\
(0.44)\end{array}$ & $\begin{array}{l}0.003 \\
(0.27)\end{array}$ & $\begin{array}{l}0.008 \\
(0.73)\end{array}$ \\
\hline Tobin $Q$ & $\begin{array}{c}0.004^{*} \\
(1.72)\end{array}$ & $\begin{array}{l}0.004 \\
(0.98)\end{array}$ & $\begin{array}{l}-0.002 \\
(-0.84)\end{array}$ & $\begin{array}{l}-0.004 \\
(-1.30)\end{array}$ & $\begin{array}{l}0.001 \\
(1.14)\end{array}$ & $\begin{array}{l}0.001 \\
(0.73)\end{array}$ & $\begin{array}{l}-0.001 \\
(-0.88)\end{array}$ & $\begin{array}{l}-0.002 \\
(-1.28)\end{array}$ & $\begin{array}{l}0.001 \\
(1.14)\end{array}$ & $\begin{array}{l}0.001 \\
(0.73)\end{array}$ & $\begin{array}{l}-0.001 \\
(-0.88)\end{array}$ & $\begin{array}{l}-0.002 \\
(-1.28)\end{array}$ \\
\hline MAValue & $\begin{array}{c}0.000 * * * \\
(3.77)\end{array}$ & $\begin{array}{c}0.000 * * \\
(2.38)\end{array}$ & $\begin{array}{c}0.000 * * \\
(2.54)\end{array}$ & $\begin{array}{c}0.000^{* * *} \\
(2.91)\end{array}$ & $\begin{array}{c}0.000 * * * \\
(3.46)\end{array}$ & $\begin{array}{c}0.000 * * \\
(2.48)\end{array}$ & $\begin{array}{c}0.000^{* * *} \\
(2.67)\end{array}$ & $\begin{array}{c}0.000 * * * \\
(3.09)\end{array}$ & $\begin{array}{c}0.000^{* * *} \\
(3.46)\end{array}$ & $\begin{array}{c}0.000 * * \\
(2.48)\end{array}$ & $\begin{array}{c}0.000^{* * *} \\
(2.67)\end{array}$ & $\begin{array}{c}0.000 * * * \\
(3.09)\end{array}$ \\
\hline Friendly & $\begin{array}{c}0.059^{* * *} \\
(2.64)\end{array}$ & $\begin{array}{c}0.059^{* * *} \\
(4.72)\end{array}$ & $\begin{array}{c}0.034^{* * *} \\
(2.66)\end{array}$ & $\begin{array}{c}0.033^{* * *} \\
(2.71)\end{array}$ & $\begin{array}{c}0.023^{* *} \\
(2.55)\end{array}$ & $\begin{array}{c}0.023^{* * *} \\
(3.91)\end{array}$ & $\begin{array}{c}0.014^{* *} \\
(2.22)\end{array}$ & $\begin{array}{c}0.014^{* *} \\
(2.19)\end{array}$ & $\begin{array}{c}0.023^{* *} \\
(2.55)\end{array}$ & $\begin{array}{c}0.023^{* * *} \\
(3.91)\end{array}$ & $\begin{array}{c}0.014^{* *} \\
(2.22)\end{array}$ & $\begin{array}{c}0.014^{* *} \\
(2.19)\end{array}$ \\
\hline Vertical & $\begin{array}{c}0.024^{* * *} \\
(2.79)\end{array}$ & $\begin{array}{c}0.024^{* * *} \\
(3.26)\end{array}$ & $\begin{array}{c}0.017^{* *} \\
(2.24)\end{array}$ & $\begin{array}{c}0.014^{*} \\
(1.93)\end{array}$ & $\begin{array}{c}0.006^{*} \\
(1.87)\end{array}$ & $\begin{array}{c}0.006^{* *} \\
(2.10)\end{array}$ & $\begin{array}{l}0.004 \\
(1.23)\end{array}$ & $\begin{array}{l}0.003 \\
(1.06)\end{array}$ & $\begin{array}{c}0.006^{*} \\
(1.87)\end{array}$ & $\begin{array}{c}0.006^{* *} \\
(2.10)\end{array}$ & $\begin{array}{l}0.004 \\
(1.23)\end{array}$ & $\begin{array}{l}0.003 \\
(1.06)\end{array}$ \\
\hline
\end{tabular}


Table A4. Cont.

\begin{tabular}{|c|c|c|c|c|c|c|c|c|c|c|c|c|}
\hline \multirow{2}{*}{ Variable } & \multicolumn{4}{|c|}{ CAR $[-2,2]$} & \multicolumn{4}{|c|}{ CAR $[-3,1]$} & \multicolumn{4}{|c|}{ CAR $[-2,1]$} \\
\hline & Model 1 & Model 2 & Model 3 & Model 4 & Model 5 & Model 6 & Model 7 & Model 8 & Model 9 & Model 10 & Model 11 & Model 12 \\
\hline Constant & $\begin{array}{c}-0.076^{* *} \\
(-2.32)\end{array}$ & $\begin{array}{c}-0.076^{* *} \\
(-2.57)\end{array}$ & $\begin{array}{c}-0.243^{* * *} \\
(-4.29)\end{array}$ & $\begin{array}{c}-0.193^{* * *} \\
(-3.73)\end{array}$ & $\begin{array}{l}-0.016 \\
(-1.19)\end{array}$ & $\begin{array}{l}-0.016 \\
(-1.41)\end{array}$ & $\begin{array}{c}-0.070^{* * *} \\
(-3.15)\end{array}$ & $\begin{array}{c}-0.052 * * * \\
(-2.60)\end{array}$ & $\begin{array}{l}-0.016 \\
(-1.19)\end{array}$ & $\begin{array}{l}-0.016 \\
(-1.41)\end{array}$ & $\begin{array}{c}-0.070^{* * *} \\
(-3.15)\end{array}$ & $\begin{array}{c}-0.052 * * * \\
(-2.60)\end{array}$ \\
\hline Year FE & No & No & Yes & Yes & No & No & Yes & Yes & No & No & Yes & Yes \\
\hline Industry FE & No & No & No & Yes & No & No & No & Yes & No & No & No & Yes \\
\hline Cluster & No & Yes & Yes & Yes & No & Yes & Yes & Yes & No & Yes & Yes & Yes \\
\hline N & 984 & 984 & 984 & 984 & 984 & 984 & 984 & 984 & 984 & 984 & 984 & 984 \\
\hline $\operatorname{Adj} R^{2}$ & 0.051 & 0.051 & 0.210 & 0.220 & 0.052 & 0.052 & 0.165 & 0.169 & 0.052 & 0.052 & 0.165 & 0.169 \\
\hline
\end{tabular}

Note: $t$-statistics in parentheses: ${ }^{*} p<0.1^{* *} p<0.05, * * * 0.01$. 
Table A5. Robustness test 2: Fama-French five-factors model.

\begin{tabular}{|c|c|c|c|c|c|c|c|}
\hline \multirow[b]{2}{*}{ Variable } & \multicolumn{5}{|c|}{ Channel One } & \multirow{2}{*}{$\begin{array}{c}\text { Channel Two } \\
\begin{array}{c}\text { Idio-risk-5factors } \\
\text { Model }\end{array}\end{array}$} & \multirow{2}{*}{$\begin{array}{l}\text { Channel Three } \\
\text { Media Evaluation }\end{array}$} \\
\hline & $\begin{array}{c}\beta_{M-5 f a c t o r s} \\
\text { Model }\end{array}$ & $\begin{array}{c}\beta_{H M L}-5 \text { factors } \\
\text { Model }\end{array}$ & $\begin{array}{c}\beta_{S M B}-5 \text { factors } \\
\text { Model }\end{array}$ & $\begin{array}{c}\beta_{R M W^{-}-5 \text { factors }} \\
\text { Model }\end{array}$ & $\begin{array}{c}\beta_{C M A}-5 \text { factors } \\
\text { Model }\end{array}$ & & \\
\hline CSR & $\begin{array}{l}0.001 \\
(0.75)\end{array}$ & $\begin{array}{l}0.001 \\
(0.19)\end{array}$ & $\begin{array}{l}-0.000 \\
(-0.05)\end{array}$ & $\begin{array}{c}-0.003^{* *} \\
(-2.48)\end{array}$ & $\begin{array}{l}0.007 \\
(1.51)\end{array}$ & $\begin{array}{l}-0.001 \\
(-0.26)\end{array}$ & $\begin{array}{c}0.128^{* * *} \\
(3.68)\end{array}$ \\
\hline Firm age & $\begin{array}{l}-0.002 \\
(-1.03)\end{array}$ & $\begin{array}{l}-0.000 \\
(-0.02)\end{array}$ & $\begin{array}{l}-0.012 \\
(-0.88)\end{array}$ & $\begin{array}{l}-0.004 \\
(-0.86)\end{array}$ & $\begin{array}{l}-0.016 \\
(-0.83)\end{array}$ & $\begin{array}{l}0.019 \\
(1.12)\end{array}$ & $\begin{array}{l}0.079 \\
(0.70)\end{array}$ \\
\hline LNTA & $\begin{array}{l}-0.013 \\
(-0.84)\end{array}$ & $\begin{array}{c}0.178 * * \\
(2.03)\end{array}$ & $\begin{array}{c}-0.360^{* * * *} \\
(-4.64)\end{array}$ & $\begin{array}{l}0.012 \\
(0.42)\end{array}$ & $\begin{array}{l}-0.146 \\
(-1.37) \\
\end{array}$ & $\begin{array}{c}-0.387^{* * *} \\
(-4.05)\end{array}$ & $\begin{array}{c}2.870 * * * \\
(3.63)\end{array}$ \\
\hline Cash ratio & $\begin{array}{l}-0.002 \\
(-0.25)\end{array}$ & $\begin{array}{l}-0.003 \\
(-0.08)\end{array}$ & $\begin{array}{l}0.000 \\
(0.01)\end{array}$ & $\begin{array}{l}0.005 \\
(0.36)\end{array}$ & $\begin{array}{l}-0.057 \\
(-0.55)\end{array}$ & $\begin{array}{l}0.033 \\
(0.52)\end{array}$ & $\begin{array}{l}-0.816 \\
(-1.49)\end{array}$ \\
\hline Liability ratio & $\begin{array}{l}0.031 \\
(0.37)\end{array}$ & $\begin{array}{l}0.466 \\
(0.82)\end{array}$ & $\begin{array}{c}1.353 * * * \\
(2.87)\end{array}$ & $\begin{array}{l}0.130 \\
(0.76)\end{array}$ & $\begin{array}{c}1.366^{* *} \\
(2.31)\end{array}$ & $\begin{array}{c}1.526^{* * *} \\
(3.02)\end{array}$ & $\begin{array}{c}-10.339 * * \\
(-2.07)\end{array}$ \\
\hline Tobin $Q$ & $\begin{array}{c}-0.021^{* * *} \\
(-2.75)\end{array}$ & $\begin{array}{l}0.062 \\
(0.96)\end{array}$ & $\begin{array}{l}0.019 \\
(0.36) \\
\end{array}$ & $\begin{array}{l}0.019 \\
(1.17) \\
\end{array}$ & $\begin{array}{l}0.070 \\
(0.82)\end{array}$ & $\begin{array}{c}-0.098^{* * *} \\
(-2.79)\end{array}$ & $\begin{array}{l}-0.471 \\
(-1.18) \\
\end{array}$ \\
\hline MAValue & $\begin{array}{c}0.000 * * \\
(2.37)\end{array}$ & $\begin{array}{l}-0.000 \\
(-1.29)\end{array}$ & $\begin{array}{l}-0.000 \\
(-0.65)\end{array}$ & $\begin{array}{c}-0.000 * * * * \\
(-2.78)\end{array}$ & $\begin{array}{l}0.000 \\
(1.24)\end{array}$ & $\begin{array}{l}0.000 \\
(0.14)\end{array}$ & $\begin{array}{l}-0.000 \\
(-0.19)\end{array}$ \\
\hline Friendly & $\begin{array}{l}-0.023 \\
(-0.38)\end{array}$ & $\begin{array}{l}-0.287 \\
(-1.20)\end{array}$ & $\begin{array}{l}0.047 \\
(0.22)\end{array}$ & $\begin{array}{l}0.106 \\
(0.84)\end{array}$ & $\begin{array}{l}0.146 \\
(0.35)\end{array}$ & $\begin{array}{l}-0.266 \\
(-0.78)\end{array}$ & $\begin{array}{l}-0.401 \\
(-0.13)\end{array}$ \\
\hline Vertical & $\begin{array}{l}0.014 \\
(0.59)\end{array}$ & $\begin{array}{l}0.131 \\
(0.87)\end{array}$ & $\begin{array}{l}-0.011 \\
(-0.07)\end{array}$ & $\begin{array}{l}-0.046 \\
(-0.96)\end{array}$ & $\begin{array}{l}-0.321 \\
(-1.01)\end{array}$ & $\begin{array}{l}-0.056 \\
(-0.28)\end{array}$ & $\begin{array}{l}-1.517 \\
(-1.29)\end{array}$ \\
\hline Constant & $\begin{array}{c}1.706^{* * * *} \\
(19.43)\end{array}$ & $\begin{array}{c}4.636^{* * * *} \\
(9.15)\end{array}$ & $\begin{array}{l}-9.101 * * * \\
(-13.42)\end{array}$ & $\begin{array}{c}1.130^{* * * *} \\
(4.17)\end{array}$ & $\begin{array}{c}-34.698^{* * * *} \\
(-26.72)\end{array}$ & $\begin{array}{c}-6.118^{* * *} \\
(-8.12)\end{array}$ & $\begin{array}{c}19.487^{* * * *} \\
(3.19)\end{array}$ \\
\hline Year FE & Yes & Yes & Yes & Yes & Yes & Yes & Yes \\
\hline Industry FE & Yes & Yes & Yes & Yes & Yes & Yes & Yes \\
\hline Cluster & Yes & Yes & Yes & Yes & Yes & Yes & Yes \\
\hline N & 1188 & 1188 & 1188 & 1032 & 1188 & 1188 & 1188 \\
\hline $\operatorname{Adj} R^{2}$ & 0.537 & 0.493 & 0.879 & 0.841 & 0.951 & 0.597 & 0.168 \\
\hline
\end{tabular}


Table A6. Robustness test 2: Fama-French five-factors model

\begin{tabular}{|c|c|c|c|c|c|c|c|c|c|c|c|c|}
\hline \multirow{2}{*}{ Variable } & \multicolumn{4}{|c|}{ CAR $[-5,5]$} & \multicolumn{4}{|c|}{ CAR $[-3,3]$} & \multicolumn{4}{|c|}{ CAR $[-1,1]$} \\
\hline & Model 1 & Model 2 & Model 3 & Model 4 & Model 5 & Model 6 & Model 7 & Model 8 & Model 9 & Model 10 & Model 11 & Model 12 \\
\hline CSR & $\begin{array}{l}-0.000 \\
(-0.83)\end{array}$ & $\begin{array}{l}-0.000 \\
(-0.88)\end{array}$ & $\begin{array}{l}-0.000 \\
(-1.07)\end{array}$ & $\begin{array}{l}-0.000 \\
(-0.70)\end{array}$ & $\begin{array}{l}-0.000 \\
(-0.66)\end{array}$ & $\begin{array}{l}-0.000 \\
(-0.69)\end{array}$ & $\begin{array}{l}-0.000 \\
(-1.06)\end{array}$ & $\begin{array}{l}-0.000 \\
(-0.66)\end{array}$ & $\begin{array}{l}-0.000 \\
(-0.42)\end{array}$ & $\begin{array}{l}-0.000 \\
(-0.44)\end{array}$ & $\begin{array}{l}-0.000 \\
(-0.68)\end{array}$ & $\begin{array}{l}-0.000 \\
(-0.19)\end{array}$ \\
\hline $\begin{array}{c}\beta_{M-3 f a c t o r s} \\
\text { Model }\end{array}$ & $\begin{array}{c}0.093 * * * \\
(7.04)\end{array}$ & $\begin{array}{c}0.093^{* * *} \\
(4.66)\end{array}$ & $\begin{array}{c}0.125^{* * *} \\
(5.39)\end{array}$ & $\begin{array}{c}0.126^{* * *} \\
(5.39)\end{array}$ & $\begin{array}{c}0.074^{* * *} \\
(7.00)\end{array}$ & $\begin{array}{c}0.074^{* * *} \\
(4.98)\end{array}$ & $\begin{array}{l}0.095 * * * \\
(5.49)\end{array}$ & $\begin{array}{c}0.096^{* * *} \\
(5.42)\end{array}$ & $\begin{array}{c}0.038^{* * *} \\
(5.73)\end{array}$ & $\begin{array}{c}0.038^{* * * *} \\
(4.61)\end{array}$ & $\begin{array}{c}0.050 * * * \\
(5.09)\end{array}$ & $\begin{array}{c}0.051^{* * *} \\
(5.03)\end{array}$ \\
\hline $\begin{array}{c}\beta_{\text {HML }}-3 \text { factors } \\
\text { Model }\end{array}$ & $\begin{array}{c}-0.005^{* *} \\
(-2.04)\end{array}$ & $\begin{array}{l}-0.005 \\
(-1.33)\end{array}$ & $\begin{array}{l}-0.007 \\
(-1.32)\end{array}$ & $\begin{array}{l}-0.005 \\
(-0.98)\end{array}$ & $\begin{array}{l}-0.004^{*} \\
(-1.81)\end{array}$ & $\begin{array}{l}-0.004 \\
(-1.29) \\
\end{array}$ & $\begin{array}{l}-0.004 \\
(-1.09) \\
\end{array}$ & $\begin{array}{l}-0.003 \\
(-0.75) \\
\end{array}$ & $\begin{array}{l}-0.002 \\
(-1.38) \\
\end{array}$ & $\begin{array}{l}-0.002 \\
(-1.10)\end{array}$ & $\begin{array}{l}-0.003 \\
(-1.05) \\
\end{array}$ & $\begin{array}{l}-0.002 \\
(-0.86) \\
\end{array}$ \\
\hline $\begin{array}{c}\beta_{S M B}-3 \text { factors } \\
\text { Model }\end{array}$ & $\begin{array}{c}0.010^{* * *} \\
(3.14)\end{array}$ & $\begin{array}{c}0.010^{* *} \\
(2.30)\end{array}$ & $\begin{array}{c}0.018^{* *} \\
(2.26)\end{array}$ & $\begin{array}{c}0.015^{*} \\
(1.89)\end{array}$ & $\begin{array}{c}0.007^{* * * *} \\
(2.78)\end{array}$ & $\begin{array}{c}0.007^{* *} \\
(2.11)\end{array}$ & $\begin{array}{c}0.012 * \\
(1.93)\end{array}$ & $\begin{array}{l}0.010 \\
(1.56)\end{array}$ & $\begin{array}{l}0.002 \\
(0.94)\end{array}$ & $\begin{array}{l}0.002 \\
(0.70)\end{array}$ & $\begin{array}{l}0.005 \\
(1.20)\end{array}$ & $\begin{array}{l}0.004 \\
(1.06)\end{array}$ \\
\hline $\begin{array}{c}\beta_{R M W}-5 \text { factors } \\
\text { Model }\end{array}$ & $\begin{array}{l}-0.002 \\
(-1.36)\end{array}$ & $\begin{array}{l}-0.002 \\
(-1.14)\end{array}$ & $\begin{array}{c}-0.015^{* * *} \\
(-3.30)\end{array}$ & $\begin{array}{c}-0.013^{* * *} \\
(-3.08)\end{array}$ & $\begin{array}{l}-0.001 \\
(-0.83)\end{array}$ & $\begin{array}{l}-0.001 \\
(-0.71)\end{array}$ & $\begin{array}{c}-0.010 \text { *** } \\
(-2.84)\end{array}$ & $\begin{array}{c}-0.009^{* *} \\
(-2.55)\end{array}$ & $\begin{array}{l}0.001 \\
(0.81)\end{array}$ & $\begin{array}{l}0.001 \\
(0.71)\end{array}$ & $\begin{array}{c}-0.005^{* *} \\
(-2.34)\end{array}$ & $\begin{array}{c}-0.005^{* *} \\
(-2.16)\end{array}$ \\
\hline $\begin{array}{c}\beta_{C M A^{-5} \text { factors }} \\
\text { Model }\end{array}$ & $\begin{array}{l}-0.003 \\
(-1.56)\end{array}$ & $\begin{array}{l}-0.003 \\
(-1.14)\end{array}$ & $\begin{array}{l}-0.005 \\
(-1.47)\end{array}$ & $\begin{array}{l}-0.004 \\
(-1.23)\end{array}$ & $\begin{array}{l}-0.003 \\
(-1.51)\end{array}$ & $\begin{array}{l}-0.003 \\
(-1.11)\end{array}$ & $\begin{array}{l}-0.003 \\
(-1.32)\end{array}$ & $\begin{array}{l}-0.003 \\
(-1.13)\end{array}$ & $\begin{array}{l}-0.002 \\
(-1.46) \\
\end{array}$ & $\begin{array}{l}-0.002 \\
(-1.05)\end{array}$ & $\begin{array}{l}-0.002 \\
(-1.13)\end{array}$ & $\begin{array}{l}-0.002 \\
(-1.14)\end{array}$ \\
\hline $\begin{array}{l}\text { Idio-risk-5factors } \\
\text { Model3factors }\end{array}$ & $\begin{array}{l}0.002 \\
(0.37)\end{array}$ & $\begin{array}{l}0.002 \\
(0.35)\end{array}$ & $\begin{array}{l}0.012 \\
(1.23)\end{array}$ & $\begin{array}{l}0.010 \\
(1.07)\end{array}$ & $\begin{array}{l}0.001 \\
(0.24)\end{array}$ & $\begin{array}{l}0.001 \\
(0.24)\end{array}$ & $\begin{array}{l}0.006 \\
(0.90)\end{array}$ & $\begin{array}{l}0.005 \\
(0.76)\end{array}$ & $\begin{array}{l}0.004 * \\
(1.69)\end{array}$ & $\begin{array}{l}0.004 \\
(1.58)\end{array}$ & $\begin{array}{c}0.009 \text { ** } \\
(2.10)\end{array}$ & $\begin{array}{l}0.008^{* *} \\
(2.01)\end{array}$ \\
\hline $\begin{array}{c}\text { Media } \\
\text { Evaluation }\end{array}$ & $\begin{array}{l}-0.000 \\
(-0.41) \\
\end{array}$ & $\begin{array}{l}-0.000 \\
(-0.41) \\
\end{array}$ & $\begin{array}{l}-0.000 \\
(-0.49) \\
\end{array}$ & $\begin{array}{l}-0.000 \\
(-0.73)\end{array}$ & $\begin{array}{l}-0.000 \\
(-0.73)\end{array}$ & $\begin{array}{l}-0.000 \\
(-0.74) \\
\end{array}$ & $\begin{array}{l}-0.000 \\
(-0.69) \\
\end{array}$ & $\begin{array}{l}-0.000 \\
(-0.89) \\
\end{array}$ & $\begin{array}{l}-0.000 \\
(-0.23) \\
\end{array}$ & $\begin{array}{l}-0.000 \\
(-0.22) \\
\end{array}$ & $\begin{array}{l}-0.000 \\
(-0.16) \\
\end{array}$ & $\begin{array}{l}-0.000 \\
(-0.48)\end{array}$ \\
\hline Firm age & $\begin{array}{l}-0.000 \\
(-0.08)\end{array}$ & $\begin{array}{l}-0.000 \\
(-0.08)\end{array}$ & $\begin{array}{l}0.000 \\
(0.00)\end{array}$ & $\begin{array}{l}0.001 \\
(0.58)\end{array}$ & $\begin{array}{l}-0.000 \\
(-0.32)\end{array}$ & $\begin{array}{l}-0.000 \\
(-0.30)\end{array}$ & $\begin{array}{l}-0.000 \\
(-0.12)\end{array}$ & $\begin{array}{l}0.000 \\
(0.48)\end{array}$ & $\begin{array}{l}-0.000 \\
(-0.79)\end{array}$ & $\begin{array}{l}-0.000 \\
(-0.68)\end{array}$ & $\begin{array}{l}-0.000 \\
(-0.52)\end{array}$ & $\begin{array}{l}0.000 \\
(0.25)\end{array}$ \\
\hline LNTA & $\begin{array}{l}-0.011 \\
(-1.56) \\
\end{array}$ & $\begin{array}{l}-0.011 \\
(-1.48) \\
\end{array}$ & $\begin{array}{l}-0.008 \\
(-1.01) \\
\end{array}$ & $\begin{array}{l}-0.009 \\
(-1.20) \\
\end{array}$ & $\begin{array}{c}-0.012 \text { ** } \\
(-2.22)\end{array}$ & $\begin{array}{c}-0.012 \text { ** } \\
(-2.06)\end{array}$ & $\begin{array}{l}-0.009 \\
(-1.49) \\
\end{array}$ & $\begin{array}{c}-0.011 * \\
(-1.73)\end{array}$ & $\begin{array}{c}-0.008^{* *} \\
(-2.34)\end{array}$ & $\begin{array}{c}-0.008 * * \\
(-2.07)\end{array}$ & $\begin{array}{l}-0.006 \\
(-1.54) \\
\end{array}$ & $\begin{array}{c}-0.007^{*} \\
(-1.82)\end{array}$ \\
\hline Cash ratio & $\begin{array}{l}-0.001 \\
(-0.24)\end{array}$ & $\begin{array}{l}-0.001 \\
(-0.13)\end{array}$ & $\begin{array}{l}-0.001 \\
(-0.14)\end{array}$ & $\begin{array}{l}0.001 \\
(0.13)\end{array}$ & $\begin{array}{l}-0.001 \\
(-0.36)\end{array}$ & $\begin{array}{l}-0.001 \\
(-0.20)\end{array}$ & $\begin{array}{l}-0.002 \\
(-0.22)\end{array}$ & $\begin{array}{l}0.000 \\
(0.07)\end{array}$ & $\begin{array}{l}-0.003 \\
(-1.23)\end{array}$ & $\begin{array}{l}-0.003 \\
(-0.77)\end{array}$ & $\begin{array}{l}-0.003 \\
(-0.77)\end{array}$ & $\begin{array}{l}-0.002 \\
(-0.47)\end{array}$ \\
\hline Liability ratio & $\begin{array}{l}-0.014 \\
(-0.38) \\
\end{array}$ & $\begin{array}{l}-0.014 \\
(-0.33) \\
\end{array}$ & $\begin{array}{l}-0.011 \\
(-0.25) \\
\end{array}$ & $\begin{array}{l}0.023 \\
(0.50) \\
\end{array}$ & $\begin{array}{l}-0.007 \\
(-0.22) \\
\end{array}$ & $\begin{array}{l}-0.007 \\
(-0.20) \\
\end{array}$ & $\begin{array}{l}-0.007 \\
(-0.22) \\
\end{array}$ & $\begin{array}{l}0.017 \\
(0.47) \\
\end{array}$ & $\begin{array}{l}-0.006 \\
(-0.34)\end{array}$ & $\begin{array}{l}-0.006 \\
(-0.31) \\
\end{array}$ & $\begin{array}{l}-0.007 \\
(-0.35) \\
\end{array}$ & $\begin{array}{l}0.010 \\
(0.48) \\
\end{array}$ \\
\hline Tobin $Q$ & $\begin{array}{l}0.004 \\
(1.39)\end{array}$ & $\begin{array}{l}0.004 \\
(0.97)\end{array}$ & $\begin{array}{l}0.005 \\
(1.58)\end{array}$ & $\begin{array}{l}0.003 \\
(0.93)\end{array}$ & $\begin{array}{l}0.003 \\
(1.22)\end{array}$ & $\begin{array}{l}0.003 \\
(0.74)\end{array}$ & $\begin{array}{l}0.004 \\
(1.22)\end{array}$ & $\begin{array}{l}0.002 \\
(0.66)\end{array}$ & $\begin{array}{l}0.001 \\
(0.71)\end{array}$ & $\begin{array}{l}0.001 \\
(0.49)\end{array}$ & $\begin{array}{l}0.002 \\
(0.93)\end{array}$ & $\begin{array}{l}0.001 \\
(0.39)\end{array}$ \\
\hline MAValue & $\begin{array}{c}0.000 * * \\
(2.44)\end{array}$ & $\begin{array}{l}0.000 \\
(1.34)\end{array}$ & $\begin{array}{l}0.000 \\
(1.43)\end{array}$ & $\begin{array}{l}0.000 \\
(1.58)\end{array}$ & $\begin{array}{c}0.000^{* * *} \\
(3.22)\end{array}$ & $\begin{array}{c}0.000 * \\
(1.88)\end{array}$ & $\begin{array}{c}0.000 \text { ** } \\
(2.00)\end{array}$ & $\begin{array}{c}0.000 * * \\
(2.18)\end{array}$ & $\begin{array}{c}0.000 * * * \\
(3.76)\end{array}$ & $\begin{array}{c}0.000 * * \\
(2.46)\end{array}$ & $\begin{array}{c}0.000 * * * \\
(2.64)\end{array}$ & $\begin{array}{c}0.000^{* * *} \\
(2.85)\end{array}$ \\
\hline Friendly & $\begin{array}{l}0.048 \\
(1.20)\end{array}$ & $\begin{array}{c}0.048^{* *} \\
(2.13)\end{array}$ & $\begin{array}{c}0.048^{* *} \\
(2.27)\end{array}$ & $\begin{array}{c}0.053^{* *} \\
(2.50)\end{array}$ & $\begin{array}{l}0.041 \\
(1.30)\end{array}$ & $\begin{array}{c}0.041 \text { ** } \\
(2.49)\end{array}$ & $\begin{array}{c}0.043^{* *} \\
(2.56)\end{array}$ & $\begin{array}{c}0.046^{* * *} \\
(2.65)\end{array}$ & $\begin{array}{l}0.027 \\
(1.36)\end{array}$ & $\begin{array}{c}0.027^{* *} \\
(2.10)\end{array}$ & $\begin{array}{l}0.026^{*} \\
(1.96)\end{array}$ & $\begin{array}{c}0.028^{* *} \\
(2.03)\end{array}$ \\
\hline
\end{tabular}


Table A6. Cont.

\begin{tabular}{|c|c|c|c|c|c|c|c|c|c|c|c|c|}
\hline \multirow{2}{*}{ Variable } & \multicolumn{4}{|c|}{ CAR $[-5,5]$} & \multicolumn{4}{|c|}{ CAR $[-3,3]$} & \multicolumn{4}{|c|}{ CAR $[-1,1]$} \\
\hline & Model 1 & Model 2 & Model 3 & Model 4 & Model 5 & Model 6 & Model 7 & Model 8 & Model 9 & Model 10 & Model 11 & Model 12 \\
\hline Vertical & $\begin{array}{c}0.039^{* * *} \\
(2.95)\end{array}$ & $\begin{array}{c}0.039^{* * *} \\
(3.44)\end{array}$ & $\begin{array}{c}0.033^{* * * *} \\
(2.94)\end{array}$ & $\begin{array}{c}0.029 * * \\
(2.47)\end{array}$ & $\begin{array}{c}0.029 * * * \\
(2.73)\end{array}$ & $\begin{array}{c}0.029^{* * *} \\
(3.07)\end{array}$ & $\begin{array}{c}0.025^{* * *} \\
(2.63)\end{array}$ & $\begin{array}{c}0.021 * * \\
(2.20)\end{array}$ & $\begin{array}{l}0.012 * \\
(1.90)\end{array}$ & $\begin{array}{c}0.012 * * \\
(2.16)\end{array}$ & $\begin{array}{l}0.010^{*} \\
(1.77)\end{array}$ & $\begin{array}{l}0.008 \\
(1.35)\end{array}$ \\
\hline Constant & $\begin{array}{c}-0.143^{* * *} \\
(-2.69)\end{array}$ & $\begin{array}{c}-0.143^{* * *} \\
(-3.08)\end{array}$ & $\begin{array}{c}-0.634^{* * *} \\
(-4.74)\end{array}$ & $\begin{array}{c}-0.653^{* * *} \\
(-5.32)\end{array}$ & $\begin{array}{c}-0.100 * * \\
(-2.35)\end{array}$ & $\begin{array}{c}-0.100^{* * *} \\
(-2.68)\end{array}$ & $\begin{array}{c}-0.446^{* * *} \\
(-4.22)\end{array}$ & $\begin{array}{c}-0.464^{* * *} \\
(-4.73)\end{array}$ & $\begin{array}{l}-0.040 \\
(-1.53)\end{array}$ & $\begin{array}{c}-0.040 * \\
(-1.77)\end{array}$ & $\begin{array}{c}-0.252 * * * \\
(-3.87)\end{array}$ & $\begin{array}{c}-0.261^{* * *} \\
(-4.29)\end{array}$ \\
\hline Year FE & No & No & Yes & Yes & No & No & Yes & Yes & No & No & Yes & Yes \\
\hline Industry FE & No & No & No & Yes & No & No & No & Yes & No & No & No & Yes \\
\hline Cluster & No & Yes & Yes & Yes & No & Yes & Yes & Yes & No & Yes & Yes & Yes \\
\hline N & 1032 & 1032 & 1032 & 1032 & 1032 & 1032 & 1032 & 1032 & 1032 & 1032 & 1032 & 1032 \\
\hline $\operatorname{Adj} R^{2}$ & 0.124 & 0.124 & 0.159 & 0.172 & 0.132 & 0.132 & 0.164 & 0.173 & 0.117 & 0.117 & 0.146 & 0.157 \\
\hline
\end{tabular}

Note: $t$-statistics in parentheses: ${ }^{*} p<0.1{ }^{* *} p<0.05,{ }^{* * *} p<0.01$ 
Table A7. Robustness Check 3: empirical impact of CSR on CAR, considering corporate ownership.

\begin{tabular}{|c|c|c|c|c|c|c|c|c|c|c|c|c|}
\hline \multirow{2}{*}{ Variable } & \multicolumn{4}{|c|}{ CAR $[-5,5]$} & \multicolumn{4}{|c|}{ CAR $[-3,3]$} & \multicolumn{4}{|c|}{ CAR $[-1,1]$} \\
\hline & Model 1 & Model 2 & Model 3 & Model 4 & Model 5 & Model 6 & Model 7 & Model 8 & Model 9 & Model 10 & Model 11 & Model 12 \\
\hline CSR & $\begin{array}{c}-0.001 * \\
(-1.69)\end{array}$ & $\begin{array}{c}-0.001 \text { * } \\
(-1.83)\end{array}$ & $\begin{array}{l}-0.000 \\
(-1.24)\end{array}$ & $\begin{array}{l}-0.000 \\
(-1.14)\end{array}$ & $\begin{array}{c}-0.001 * \\
(-1.69)\end{array}$ & $\begin{array}{c}-0.001 \text { * } \\
(-1.81)\end{array}$ & $\begin{array}{l}-0.000 \\
(-1.18)\end{array}$ & $\begin{array}{l}-0.000 \\
(-0.97)\end{array}$ & $\begin{array}{c}-0.000 * \\
(-1.68)\end{array}$ & $\begin{array}{c}-0.000 * \\
(-1.69)\end{array}$ & $\begin{array}{l}-0.000 \\
(-1.10)\end{array}$ & $\begin{array}{l}-0.000 \\
(-0.82)\end{array}$ \\
\hline$C S R * S O E$ & $\begin{array}{l}0.000 \\
(0.21)\end{array}$ & $\begin{array}{l}0.000 \\
(0.26)\end{array}$ & $\begin{array}{l}-0.000 \\
(-0.00)\end{array}$ & $\begin{array}{l}0.000 \\
(0.24)\end{array}$ & $\begin{array}{l}0.000 \\
(0.54)\end{array}$ & $\begin{array}{l}0.000 \\
(0.62)\end{array}$ & $\begin{array}{l}0.000 \\
(0.25)\end{array}$ & $\begin{array}{l}0.000 \\
(0.39)\end{array}$ & $\begin{array}{l}0.000 \\
(1.20)\end{array}$ & $\begin{array}{l}0.000 \\
(1.30)\end{array}$ & $\begin{array}{l}0.000 \\
(0.91)\end{array}$ & $\begin{array}{l}0.000 \\
(1.08)\end{array}$ \\
\hline Firm age & $\begin{array}{l}0.000 \\
(0.01)\end{array}$ & $\begin{array}{l}0.000 \\
(0.01)\end{array}$ & $\begin{array}{l}-0.000 \\
(-0.12)\end{array}$ & $\begin{array}{l}0.000 \\
(0.52)\end{array}$ & $\begin{array}{l}0.000 \\
(0.08)\end{array}$ & $\begin{array}{l}0.000 \\
(0.08)\end{array}$ & $\begin{array}{l}-0.000 \\
(-0.08)\end{array}$ & $\begin{array}{l}0.000 \\
(0.59)\end{array}$ & $\begin{array}{l}0.000 \\
(0.04)\end{array}$ & $\begin{array}{l}0.000 \\
(0.03)\end{array}$ & $\begin{array}{l}-0.000 \\
(-0.14)\end{array}$ & $\begin{array}{l}0.000 \\
(0.79)\end{array}$ \\
\hline LNTA & $\begin{array}{l}-0.009 \\
(-1.48)\end{array}$ & $\begin{array}{l}-0.009 \\
(-1.46)\end{array}$ & $\begin{array}{c}-0.012 * \\
(-1.88)\end{array}$ & $\begin{array}{c}-0.015^{* *} \\
(-2.19)\end{array}$ & $\begin{array}{c}-0.010 * * \\
(-2.10)\end{array}$ & $\begin{array}{c}-0.010 \text { ** } \\
(-2.06)\end{array}$ & $\begin{array}{c}-0.012 \text { ** } \\
(-2.37)\end{array}$ & $\begin{array}{c}-0.015^{* * *} \\
(-2.77)\end{array}$ & $\begin{array}{c}-0.007^{* *} \\
(-2.29)\end{array}$ & $\begin{array}{c}-0.007^{* *} \\
(-2.12)\end{array}$ & $\begin{array}{c}-0.008^{* *} \\
(-2.33)\end{array}$ & $\begin{array}{c}-0.010 \text { *** } \\
(-2.87)\end{array}$ \\
\hline Cash ratio & $\begin{array}{l}-0.002 \\
(-0.44)\end{array}$ & $\begin{array}{l}-0.002 \\
(-0.24)\end{array}$ & $\begin{array}{l}0.001 \\
(0.13)\end{array}$ & $\begin{array}{l}0.002 \\
(0.33)\end{array}$ & $\begin{array}{l}-0.003 \\
(-0.82)\end{array}$ & $\begin{array}{l}-0.003 \\
(-0.45)\end{array}$ & $\begin{array}{l}-0.000 \\
(-0.05)\end{array}$ & $\begin{array}{l}0.001 \\
(0.18)\end{array}$ & $\begin{array}{c}-0.004 * \\
(-1.79)\end{array}$ & $\begin{array}{l}-0.004 \\
(-1.06)\end{array}$ & $\begin{array}{l}-0.002 \\
(-0.71)\end{array}$ & $\begin{array}{l}-0.001 \\
(-0.42)\end{array}$ \\
\hline Liability ratio & $\begin{array}{l}0.004 \\
(0.12)\end{array}$ & $\begin{array}{l}0.004 \\
(0.10)\end{array}$ & $\begin{array}{l}0.005 \\
(0.13)\end{array}$ & $\begin{array}{l}0.028 \\
(0.66)\end{array}$ & $\begin{array}{l}0.004 \\
(0.15)\end{array}$ & $\begin{array}{l}0.004 \\
(0.13)\end{array}$ & $\begin{array}{l}0.004 \\
(0.14)\end{array}$ & $\begin{array}{l}0.023 \\
(0.68)\end{array}$ & $\begin{array}{l}-0.002 \\
(-0.09)\end{array}$ & $\begin{array}{l}-0.002 \\
(-0.08)\end{array}$ & $\begin{array}{l}-0.002 \\
(-0.08)\end{array}$ & $\begin{array}{l}0.012 \\
(0.62)\end{array}$ \\
\hline Tobin $Q$ & $\begin{array}{c}0.007^{* * *} \\
(3.04)\end{array}$ & $\begin{array}{c}0.007^{* *} \\
(2.01)\end{array}$ & $\begin{array}{l}0.003 \\
(0.65)\end{array}$ & $\begin{array}{l}0.000 \\
(0.11)\end{array}$ & $\begin{array}{c}0.006^{* * *} \\
(3.07)\end{array}$ & $\begin{array}{c}0.006^{*} \\
(1.86)\end{array}$ & $\begin{array}{l}0.002 \\
(0.56)\end{array}$ & $\begin{array}{l}0.000 \\
(0.08)\end{array}$ & $\begin{array}{c}0.003^{* *} \\
(2.57)\end{array}$ & $\begin{array}{c}0.003 * \\
(1.68)\end{array}$ & $\begin{array}{l}0.001 \\
(0.35)\end{array}$ & $\begin{array}{l}-0.000 \\
(-0.13)\end{array}$ \\
\hline MAValue & $\begin{array}{c}0.000^{* * *} \\
(3.08)\end{array}$ & $\begin{array}{l}0.000 \\
(1.52)\end{array}$ & $\begin{array}{l}0.000 \\
(1.45)\end{array}$ & $\begin{array}{l}0.000 \\
(1.55)\end{array}$ & $\begin{array}{c}0.000^{* * *} \\
(3.94)\end{array}$ & $\begin{array}{c}0.000 * * \\
(2.01)\end{array}$ & $\begin{array}{c}0.000 * * \\
(1.98)\end{array}$ & $\begin{array}{c}0.000^{* *} \\
(2.11)\end{array}$ & $\begin{array}{c}0.000^{* * *} \\
(4.56)\end{array}$ & $\begin{array}{c}0.000^{* *} \\
(2.55)\end{array}$ & $\begin{array}{c}0.000 \text { ** } \\
(2.56)\end{array}$ & $\begin{array}{c}0.000^{* * *} \\
(2.80)\end{array}$ \\
\hline Friendly & $\begin{array}{c}0.057^{*} \\
(1.65)\end{array}$ & $\begin{array}{c}0.057^{* * *} \\
(3.01)\end{array}$ & $\begin{array}{l}0.033 * \\
(1.78)\end{array}$ & $\begin{array}{l}0.031 \\
(1.61)\end{array}$ & $\begin{array}{c}0.052 * \\
(1.91)\end{array}$ & $\begin{array}{c}0.052^{* * *} \\
(3.90)\end{array}$ & $\begin{array}{c}0.031 \text { ** } \\
(2.19)\end{array}$ & $\begin{array}{c}0.030 \text { ** } \\
(1.97)\end{array}$ & $\begin{array}{c}0.040 \text { ** } \\
(2.35)\end{array}$ & $\begin{array}{c}0.040 * * * \\
(4.13)\end{array}$ & $\begin{array}{c}0.026^{* *} \\
(2.42)\end{array}$ & $\begin{array}{c}0.025^{* *} \\
(2.35)\end{array}$ \\
\hline Vertical & $\begin{array}{c}0.042^{* * *} \\
(3.45)\end{array}$ & $\begin{array}{c}0.042^{* * *} \\
(4.12)\end{array}$ & $\begin{array}{c}0.036^{* * *} \\
(3.50)\end{array}$ & $\begin{array}{c}0.035^{* * *} \\
(3.24)\end{array}$ & $\begin{array}{c}0.032^{* * *} \\
(3.30)\end{array}$ & $\begin{array}{c}0.032^{* * *} \\
(3.80)\end{array}$ & $\begin{array}{c}0.027^{* * *} \\
(3.17)\end{array}$ & $\begin{array}{c}0.026^{* * *} \\
(2.93)\end{array}$ & $\begin{array}{c}0.014^{* *} \\
(2.31)\end{array}$ & $\begin{array}{c}0.014^{* * *} \\
(2.64)\end{array}$ & $\begin{array}{c}0.011 \text { ** } \\
(2.04)\end{array}$ & $\begin{array}{l}0.010^{*} \\
(1.85)\end{array}$ \\
\hline Constant & $\begin{array}{l}-0.020 \\
(-0.47) \\
\end{array}$ & $\begin{array}{l}-0.020 \\
(-0.60) \\
\end{array}$ & $\begin{array}{l}-0.026 \\
(-0.76) \\
\end{array}$ & $\begin{array}{c}-0.079 * * \\
(-1.98)\end{array}$ & $\begin{array}{l}-0.016 \\
(-0.47) \\
\end{array}$ & $\begin{array}{l}-0.016 \\
(-0.60) \\
\end{array}$ & $\begin{array}{l}-0.021 \\
(-0.77) \\
\end{array}$ & $\begin{array}{c}-0.065 * * \\
(-2.01)\end{array}$ & $\begin{array}{l}-0.005 \\
(-0.25) \\
\end{array}$ & $\begin{array}{l}-0.005 \\
(-0.31) \\
\end{array}$ & $\begin{array}{l}-0.008 \\
(-0.46) \\
\end{array}$ & $\begin{array}{l}-0.031 \\
(-1.44)\end{array}$ \\
\hline Year FE & No & No & Yes & Yes & No & No & Yes & Yes & No & No & Yes & Yes \\
\hline Industry FE & No & No & No & Yes & No & No & No & Yes & No & No & No & Yes \\
\hline Cluster & No & Yes & Yes & Yes & No & Yes & Yes & Yes & No & Yes & Yes & Yes \\
\hline$N$ & 1188 & 1188 & 1188 & 1188 & 1188 & 1188 & 1188 & 1188 & 1188 & 1188 & 1188 & 1188 \\
\hline Adj. $R^{2}$ & 0.039 & 0.039 & 0.096 & 0.111 & 0.047 & 0.047 & 0.111 & 0.124 & 0.043 & 0.043 & 0.110 & 0.126 \\
\hline
\end{tabular}


Table A8. Robustness check 3: impact of CSR on channels, considering corporate ownership.

\begin{tabular}{|c|c|c|c|c|c|}
\hline \multirow{2}{*}{ Variable } & \multicolumn{3}{|c|}{ Channel One } & \multirow{2}{*}{$\begin{array}{c}\text { Channel Two } \\
\text { Idio-risk-3factors Model }\end{array}$} & \multirow{2}{*}{$\begin{array}{c}\text { Channel Three } \\
\text { Media Evaluation }\end{array}$} \\
\hline & $\beta_{M}$-3factors Model & $\beta_{H M L}-3$ factors Model & $\beta_{S M B}-3$ factors Model & & \\
\hline CSR & $\begin{array}{l}-0.001 \\
(-0.98)\end{array}$ & $\begin{array}{l}0.002 \\
(0.63)\end{array}$ & $\begin{array}{l}-0.000 \\
(-0.19)\end{array}$ & $\begin{array}{l}0.000 \\
(1.60)\end{array}$ & $\begin{array}{c}0.119 * * * \\
(2.66)\end{array}$ \\
\hline CSR SOE & $\begin{array}{c}0.002 * * * \\
(2.74)\end{array}$ & $\begin{array}{l}0.002 \\
(0.57)\end{array}$ & $\begin{array}{l}-0.001 \\
(-0.44)\end{array}$ & $\begin{array}{c}-0.000 * \\
(-1.66)\end{array}$ & $\begin{array}{l}0.015 \\
(0.39)\end{array}$ \\
\hline Firm age & $\begin{array}{l}-0.001 \\
(-0.55)\end{array}$ & $\begin{array}{l}0.001 \\
(0.13)\end{array}$ & $\begin{array}{l}-0.003 \\
(-0.43)\end{array}$ & $\begin{array}{l}-0.000 \\
(-0.93)\end{array}$ & $\begin{array}{l}0.076 \\
(0.67)\end{array}$ \\
\hline LNTA & $\begin{array}{l}0.014 \\
(0.78)\end{array}$ & $\begin{array}{l}0.003 \\
(0.04)\end{array}$ & $\begin{array}{c}-0.222 * * * \\
(-4.76)\end{array}$ & $\begin{array}{l}0.001 \\
(0.76)\end{array}$ & $\begin{array}{l}2.818^{* * *} \\
(3.53)\end{array}$ \\
\hline Cash ratio & $\begin{array}{l}-0.005 \\
(-0.62)\end{array}$ & $\begin{array}{l}0.047 \\
(1.38)\end{array}$ & $\begin{array}{l}0.027 \\
(1.33)\end{array}$ & $\begin{array}{l}0.000 \\
(1.08)\end{array}$ & $\begin{array}{l}-0.823 \\
(-1.50)\end{array}$ \\
\hline Liability ratio & $\begin{array}{l}-0.093 \\
(-1.05)\end{array}$ & $\begin{array}{c}0.698 * \\
(1.77)\end{array}$ & $\begin{array}{c}0.699 * * \\
(2.58)\end{array}$ & $\begin{array}{l}0.014^{* * *} \\
(3.05)\end{array}$ & $\begin{array}{c}-10.452 * * \\
(-2.09)\end{array}$ \\
\hline Tobin $Q$ & $\begin{array}{c}-0.020 \text { ** } \\
(-2.06)\end{array}$ & $\begin{array}{l}0.030 \\
(0.76)\end{array}$ & $\begin{array}{l}-0.006 \\
(-0.24)\end{array}$ & $\begin{array}{l}0.001 \\
(1.45)\end{array}$ & $\begin{array}{l}-0.471 \\
(-1.18)\end{array}$ \\
\hline MAValue & $\begin{array}{c}0.000 * \\
(1.76) \\
\end{array}$ & $\begin{array}{l}-0.000 \\
(-1.10)\end{array}$ & $\begin{array}{l}-0.000 * \\
(-1.85)\end{array}$ & $\begin{array}{l}-0.000 \\
(-1.57) \\
\end{array}$ & $\begin{array}{l}-0.000 \\
(-0.09)\end{array}$ \\
\hline Friendly & $\begin{array}{l}-0.054 \\
(-0.86)\end{array}$ & $\begin{array}{l}-0.174 \\
(-0.89)\end{array}$ & $\begin{array}{l}-0.029 \\
(-0.22)\end{array}$ & $\begin{array}{l}-0.001 \\
(-0.79)\end{array}$ & $\begin{array}{l}-0.428 \\
(-0.14)\end{array}$ \\
\hline Vertical & $\begin{array}{l}0.025 \\
(0.99)\end{array}$ & $\begin{array}{l}0.122 \\
(1.09)\end{array}$ & $\begin{array}{l}0.065 \\
(1.00)\end{array}$ & $\begin{array}{l}-0.001 \\
(-0.48) \\
\end{array}$ & $\begin{array}{l}-1.493 \\
(-1.27)\end{array}$ \\
\hline Constant & $\begin{array}{l}2.619^{* * *} \\
(26.93)\end{array}$ & $\begin{array}{l}2.769^{* * *} \\
(6.43)\end{array}$ & $\begin{array}{c}3.281^{* * *} \\
(13.18)\end{array}$ & $\begin{array}{l}0.267^{* * *} \\
(51.55)\end{array}$ & $\begin{array}{c}19.507^{* * *} \\
(3.19)\end{array}$ \\
\hline Year FE & Yes & Yes & Yes & Yes & Yes \\
\hline Industry FE & Yes & Yes & Yes & Yes & Yes \\
\hline Cluster & Yes & Yes & Yes & Yes & Yes \\
\hline$N$ & 1188 & 1188 & 1188 & 1188 & 1188 \\
\hline $\operatorname{Adj} . R^{2}$ & 0.752 & 0.680 & 0.697 & 0.975 & 0.167 \\
\hline
\end{tabular}


Table A9. Robustness check 3: impact of acquirer's CSR on the CAR through three channels, considering corporate ownership.

\begin{tabular}{|c|c|c|c|c|c|c|c|c|c|c|c|c|}
\hline \multirow{2}{*}{ Variable } & \multicolumn{4}{|c|}{ CAR $[-5,5]$} & \multicolumn{4}{|c|}{ CAR $[-3,3]$} & \multicolumn{4}{|c|}{ CAR $[-1,1]$} \\
\hline & Model 1 & Model 2 & Model 3 & Model 4 & Model 5 & Model 6 & Model 7 & Model 8 & Model 9 & Model 10 & Model 11 & Model 12 \\
\hline CSR & $\begin{array}{l}-0.001 \\
(-1.55)\end{array}$ & $\begin{array}{c}-0.001 * \\
(-1.68)\end{array}$ & $\begin{array}{l}-0.000 \\
(-0.45)\end{array}$ & $\begin{array}{l}-0.000 \\
(-0.19)\end{array}$ & $\begin{array}{l}-0.001 \\
(-1.57)\end{array}$ & $\begin{array}{c}-0.001 * \\
(-1.69)\end{array}$ & $\begin{array}{l}-0.000 \\
(-0.52)\end{array}$ & $\begin{array}{l}-0.000 \\
(-0.17)\end{array}$ & $\begin{array}{l}-0.000 \\
(-1.59)\end{array}$ & $\begin{array}{l}-0.000 \\
(-1.60)\end{array}$ & $\begin{array}{l}-0.000 \\
(-0.61)\end{array}$ & $\begin{array}{l}-0.000 \\
(-0.29)\end{array}$ \\
\hline CSR SOE & $\begin{array}{l}0.000 \\
(0.26)\end{array}$ & $\begin{array}{l}0.000 \\
(0.30)\end{array}$ & $\begin{array}{l}0.000 \\
(0.26)\end{array}$ & $\begin{array}{l}-0.000 \\
(-0.03)\end{array}$ & $\begin{array}{l}0.000 \\
(0.69)\end{array}$ & $\begin{array}{l}0.000 \\
(0.78)\end{array}$ & $\begin{array}{l}0.000 \\
(0.68)\end{array}$ & $\begin{array}{l}0.000 \\
(0.32)\end{array}$ & $\begin{array}{l}0.000 \\
(1.22)\end{array}$ & $\begin{array}{l}0.000 \\
(1.31)\end{array}$ & $\begin{array}{l}0.000 \\
(1.23)\end{array}$ & $\begin{array}{l}0.000 \\
(1.02)\end{array}$ \\
\hline $\begin{array}{c}\beta_{M^{-3}-3 \text { factors }} \\
\text { Model }\end{array}$ & $\begin{array}{c}0.024^{* *} \\
(2.51)\end{array}$ & $\begin{array}{c}0.024 * * \\
(1.98)\end{array}$ & $\begin{array}{c}0.087^{* * *} \\
(4.43)\end{array}$ & $\begin{array}{c}0.085^{* * *} \\
(4.40)\end{array}$ & $\begin{array}{c}0.018^{* *} \\
(2.42)\end{array}$ & $\begin{array}{c}0.018^{* *} \\
(2.00)\end{array}$ & $\begin{array}{c}0.066^{* * * *} \\
(4.40)\end{array}$ & $\begin{array}{c}0.063^{* * *} \\
(4.17)\end{array}$ & $\begin{array}{c}0.010^{* *} \\
(2.23)\end{array}$ & $\begin{array}{c}0.010 * \\
(1.83)\end{array}$ & $\begin{array}{c}0.037^{* * *} \\
(4.13)\end{array}$ & $\begin{array}{c}0.035^{* * *} \\
(3.81)\end{array}$ \\
\hline $\begin{array}{c}\beta_{H M L}-3 \text { factors } \\
\text { Model }\end{array}$ & $\begin{array}{l}-0.003 \\
(-1.14)\end{array}$ & $\begin{array}{l}-0.003 \\
(-0.91)\end{array}$ & $\begin{array}{l}-0.012 \\
(-1.52)\end{array}$ & $\begin{array}{l}-0.010 \\
(-1.29)\end{array}$ & $\begin{array}{l}-0.003 \\
(-1.32)\end{array}$ & $\begin{array}{l}-0.003 \\
(-1.17)\end{array}$ & $\begin{array}{l}-0.010 \\
(-1.61)\end{array}$ & $\begin{array}{l}-0.008 \\
(-1.33)\end{array}$ & $\begin{array}{l}-0.002 \\
(-1.48)\end{array}$ & $\begin{array}{l}-0.002 \\
(-1.31)\end{array}$ & $\begin{array}{l}-0.005 \\
(-1.36)\end{array}$ & $\begin{array}{l}-0.004 \\
(-1.14)\end{array}$ \\
\hline $\begin{array}{c}\beta_{S M B}-3 \text { factors } \\
\text { Model }\end{array}$ & $\begin{array}{c}0.007^{*} \\
(1.67)\end{array}$ & $\begin{array}{l}0.007 \\
(1.34)\end{array}$ & $\begin{array}{l}0.019 \\
(1.49)\end{array}$ & $\begin{array}{l}0.018 \\
(1.46)\end{array}$ & $\begin{array}{l}0.005 \\
(1.46)\end{array}$ & $\begin{array}{l}0.005 \\
(1.24)\end{array}$ & $\begin{array}{l}0.015 \\
(1.62)\end{array}$ & $\begin{array}{l}0.014 \\
(1.55)\end{array}$ & $\begin{array}{l}0.000 \\
(0.11)\end{array}$ & $\begin{array}{l}0.000 \\
(0.09)\end{array}$ & $\begin{array}{l}0.007 \\
(1.12)\end{array}$ & $\begin{array}{l}0.006 \\
(1.07)\end{array}$ \\
\hline $\begin{array}{c}\text { Idio-risk-3factors } \\
\text { Model3factors }\end{array}$ & $\begin{array}{c}0.009^{* *} \\
(2.04)\end{array}$ & $\begin{array}{l}0.009 \\
(1.39)\end{array}$ & $\begin{array}{c}0.020^{* *} \\
(2.25)\end{array}$ & $\begin{array}{c}0.020^{* *} \\
(2.24)\end{array}$ & $\begin{array}{l}0.006^{*} \\
(1.80)\end{array}$ & $\begin{array}{l}0.006 \\
(1.38)\end{array}$ & $\begin{array}{c}0.016^{* *} \\
(2.39)\end{array}$ & $\begin{array}{c}0.017^{* *} \\
(2.39)\end{array}$ & $\begin{array}{c}0.005^{* *} \\
(2.09)\end{array}$ & $\begin{array}{l}0.005 \\
(1.59)\end{array}$ & $\begin{array}{c}0.013^{* * *} \\
(3.39)\end{array}$ & $\begin{array}{c}0.014^{* * *} \\
(3.38)\end{array}$ \\
\hline $\begin{array}{c}\text { Media } \\
\text { Evaluation }\end{array}$ & $\begin{array}{l}0.000 \\
(1.59)\end{array}$ & $\begin{array}{l}0.000 \\
(1.49)\end{array}$ & $\begin{array}{l}-0.000 \\
(-0.41)\end{array}$ & $\begin{array}{l}-0.000 \\
(-0.47)\end{array}$ & $\begin{array}{l}0.000 \\
(1.42)\end{array}$ & $\begin{array}{l}0.000 \\
(1.32)\end{array}$ & $\begin{array}{l}-0.000 \\
(-0.52)\end{array}$ & $\begin{array}{l}-0.000 \\
(-0.62)\end{array}$ & $\begin{array}{l}0.000 \\
(1.58)\end{array}$ & $\begin{array}{l}0.000 \\
(1.45)\end{array}$ & $\begin{array}{l}-0.000 \\
(-0.04)\end{array}$ & $\begin{array}{l}-0.000 \\
(-0.34)\end{array}$ \\
\hline Firm age & $\begin{array}{l}0.001 \\
(0.72)\end{array}$ & $\begin{array}{l}0.001 \\
(0.75)\end{array}$ & $\begin{array}{l}0.000 \\
(0.12)\end{array}$ & $\begin{array}{l}0.000 \\
(0.54)\end{array}$ & $\begin{array}{l}0.001 \\
(0.69)\end{array}$ & $\begin{array}{l}0.001 \\
(0.70)\end{array}$ & $\begin{array}{l}0.000 \\
(0.17)\end{array}$ & $\begin{array}{l}0.000 \\
(0.61)\end{array}$ & $\begin{array}{l}0.000 \\
(0.59)\end{array}$ & $\begin{array}{l}0.000 \\
(0.64)\end{array}$ & $\begin{array}{l}0.000 \\
(0.15)\end{array}$ & $\begin{array}{l}0.000 \\
(0.74)\end{array}$ \\
\hline LNTA & $\begin{array}{l}-0.010 \\
(-1.48)\end{array}$ & $\begin{array}{l}-0.010 \\
(-1.44)\end{array}$ & $\begin{array}{c}-0.012 * \\
(-1.75)\end{array}$ & $\begin{array}{c}-0.014 \text { ** } \\
(-1.99)\end{array}$ & $\begin{array}{c}-0.013^{* *} \\
(-2.31)\end{array}$ & $\begin{array}{c}-0.013^{* *} \\
(-2.29)\end{array}$ & $\begin{array}{c}-0.013 \text { ** } \\
(-2.35)\end{array}$ & $\begin{array}{c}-0.015^{* * *} \\
(-2.65)\end{array}$ & $\begin{array}{c}-0.009 * * * \\
(-2.76)\end{array}$ & $\begin{array}{c}-0.009 * * * \\
(-2.59)\end{array}$ & $\begin{array}{c}-0.009 \text { ** } \\
(-2.45)\end{array}$ & $\begin{array}{c}-0.010^{* * *} \\
(-2.76)\end{array}$ \\
\hline Cash ratio & $\begin{array}{l}-0.004 \\
(-0.80)\end{array}$ & $\begin{array}{l}-0.004 \\
(-0.39)\end{array}$ & $\begin{array}{l}0.003 \\
(0.35)\end{array}$ & $\begin{array}{l}0.004 \\
(0.55)\end{array}$ & $\begin{array}{l}-0.003 \\
(-0.98)\end{array}$ & $\begin{array}{l}-0.003 \\
(-0.50)\end{array}$ & $\begin{array}{l}0.001 \\
(0.23)\end{array}$ & $\begin{array}{l}0.003 \\
(0.46)\end{array}$ & $\begin{array}{c}-0.004 * \\
(-1.74)\end{array}$ & $\begin{array}{l}-0.004 \\
(-1.00)\end{array}$ & $\begin{array}{l}-0.001 \\
(-0.35)\end{array}$ & $\begin{array}{l}-0.000 \\
(-0.09)\end{array}$ \\
\hline Liability ratio & $\begin{array}{l}-0.026 \\
(-0.68)\end{array}$ & $\begin{array}{l}-0.026 \\
(-0.55)\end{array}$ & $\begin{array}{l}-0.022 \\
(-0.54)\end{array}$ & $\begin{array}{l}0.005 \\
(0.11)\end{array}$ & $\begin{array}{l}-0.010 \\
(-0.34)\end{array}$ & $\begin{array}{l}-0.010 \\
(-0.28)\end{array}$ & $\begin{array}{l}-0.011 \\
(-0.34)\end{array}$ & $\begin{array}{l}0.012 \\
(0.37)\end{array}$ & $\begin{array}{l}-0.003 \\
(-0.15)\end{array}$ & $\begin{array}{l}-0.003 \\
(-0.13)\end{array}$ & $\begin{array}{l}-0.005 \\
(-0.27)\end{array}$ & $\begin{array}{l}0.011 \\
(0.54)\end{array}$ \\
\hline Tobin $Q$ & $\begin{array}{c}0.008^{* *} \\
(2.34)\end{array}$ & $\begin{array}{l}0.008 \\
(1.33)\end{array}$ & $\begin{array}{l}-0.001 \\
(-0.27) \\
\end{array}$ & $\begin{array}{l}-0.003 \\
(-0.85) \\
\end{array}$ & $\begin{array}{c}0.005^{*} \\
(1.89)\end{array}$ & $\begin{array}{l}0.005 \\
(1.10)\end{array}$ & $\begin{array}{l}-0.002 \\
(-0.69)\end{array}$ & $\begin{array}{l}-0.004 \\
(-1.30)\end{array}$ & $\begin{array}{l}0.002 \\
(1.52)\end{array}$ & $\begin{array}{l}0.002 \\
(0.88)\end{array}$ & $\begin{array}{l}-0.002 \\
(-0.86)\end{array}$ & $\begin{array}{l}-0.003 \\
(-1.36)\end{array}$ \\
\hline MAValue & $\begin{array}{c}0.000^{* * *} \\
(2.88)\end{array}$ & $\begin{array}{l}0.000 \\
(1.59)\end{array}$ & $\begin{array}{l}0.000 \\
(1.55)\end{array}$ & $\begin{array}{c}0.000 * \\
(1.73)\end{array}$ & $\begin{array}{c}0.000^{* * *} \\
(3.65)\end{array}$ & $\begin{array}{c}0.000 * * \\
(2.19)\end{array}$ & $\begin{array}{c}0.000 * * \\
(2.29)\end{array}$ & $\begin{array}{c}0.000 * * * \\
(2.59)\end{array}$ & $\begin{array}{c}0.000 * * * \\
(4.18)\end{array}$ & $\begin{array}{c}0.000 * * * \\
(2.90)\end{array}$ & $\begin{array}{c}0.000^{* * *} \\
(3.23)\end{array}$ & $\begin{array}{c}0.000 * * * \\
(3.68)\end{array}$ \\
\hline Friendly & $\begin{array}{c}0.074^{* *} \\
(2.19)\end{array}$ & $\begin{array}{c}0.074^{* * *} \\
(3.38)\end{array}$ & $\begin{array}{c}0.034^{*} \\
(1.75)\end{array}$ & $\begin{array}{c}0.033 * \\
(1.71)\end{array}$ & $\begin{array}{c}0.064^{* *} \\
(2.36)\end{array}$ & $\begin{array}{c}0.064^{* * *} \\
(4.22)\end{array}$ & $\begin{array}{c}0.032 * * \\
(2.15)\end{array}$ & $\begin{array}{c}0.032 * * \\
(2.09)\end{array}$ & $\begin{array}{c}0.043 * * * \\
(2.63)\end{array}$ & $\begin{array}{c}0.043^{* * *} \\
(4.32)\end{array}$ & $\begin{array}{c}0.026^{* *} \\
(2.29)\end{array}$ & $\begin{array}{c}0.025^{* *} \\
(2.33)\end{array}$ \\
\hline Vertical & $\begin{array}{c}0.042^{* * *} \\
(3.20)\end{array}$ & $\begin{array}{c}0.042^{* * *} \\
(3.69)\end{array}$ & $\begin{array}{c}0.029 * * * \\
(2.65)\end{array}$ & $\begin{array}{c}0.026^{* *} \\
(2.33)\end{array}$ & $\begin{array}{c}0.033 * * * \\
(3.14)\end{array}$ & $\begin{array}{c}0.033^{* * *} \\
(3.58)\end{array}$ & $\begin{array}{c}0.023^{* *} \\
(2.52)\end{array}$ & $\begin{array}{c}0.020 * * \\
(2.20)\end{array}$ & $\begin{array}{c}0.019 * * * \\
(2.97)\end{array}$ & $\begin{array}{c}0.019 * * * \\
(3.48)\end{array}$ & $\begin{array}{c}0.014^{* *} \\
(2.54)\end{array}$ & $\begin{array}{c}0.012^{* *} \\
(2.18)\end{array}$ \\
\hline
\end{tabular}


Table A9. Cont.

\begin{tabular}{|c|c|c|c|c|c|c|c|c|c|c|c|c|}
\hline \multirow{2}{*}{ Variable } & \multicolumn{4}{|c|}{ CAR $[-5,5]$} & \multicolumn{4}{|c|}{ CAR $[-3,3]$} & \multicolumn{4}{|c|}{ CAR $[-1,1]$} \\
\hline & Model 1 & Model 2 & Model 3 & Model 4 & Model 5 & Model 6 & Model 7 & Model 8 & Model 9 & Model 10 & Model 11 & Model 12 \\
\hline Constant & $\begin{array}{c}-0.110^{* *} \\
(-2.22)\end{array}$ & $\begin{array}{c}-0.110 \text { ** } \\
(-2.42)\end{array}$ & $\begin{array}{c}-0.364^{* * *} \\
(-3.99)\end{array}$ & $\begin{array}{c}-0.267^{* * *} \\
(-3.52)\end{array}$ & $\begin{array}{c}-0.081^{* *} \\
(-2.04)\end{array}$ & $\begin{array}{c}-0.081 \text { ** } \\
(-2.23)\end{array}$ & $\begin{array}{c}-0.285^{* * *} \\
(-4.07)\end{array}$ & $\begin{array}{c}-0.213^{* * *} \\
(-3.56)\end{array}$ & $\begin{array}{c}-0.046^{*} \\
(-1.88)\end{array}$ & $\begin{array}{c}-0.046^{* *} \\
(-2.06)\end{array}$ & $\begin{array}{c}-0.177^{* * *} \\
(-4.10)\end{array}$ & $\begin{array}{c}-0.141^{* * *} \\
(-3.73)\end{array}$ \\
\hline Year FE & No & No & Yes & Yes & No & No & Yes & Yes & No & No & Yes & Yes \\
\hline Industry FE & No & No & No & Yes & No & No & No & Yes & No & No & No & Yes \\
\hline Cluster & No & Yes & Yes & Yes & No & Yes & Yes & Yes & No & Yes & Yes & Yes \\
\hline N & 984 & 984 & 984 & 984 & 984 & 984 & 984 & 984 & 984 & 984 & 984 & 984 \\
\hline Adj. $R^{2}$ & 0.054 & 0.054 & 0.228 & 0.245 & 0.056 & 0.056 & 0.229 & 0.241 & 0.059 & 0.059 & 0.198 & 0.208 \\
\hline
\end{tabular}

Note: $t$-statistics in parentheses: ${ }^{*} p<0.1{ }^{* *} p<0.05,{ }^{* * *} p<0.01$. 


\section{References}

1. Swanson, D.L. Addressing a Theoretical Problem by Reorienting the Corporate Social Performance Model. Acad. Manag. Rev. 1995, 20, 43-64. [CrossRef]

2. Campbell, J.L. Why would Corporations Behave in Socially Responsible Ways? An Institutional Theory of Corporate Social Responsibility. Acad. Manag. Rev. 2007, 32, 946-967. [CrossRef]

3. Khanna, T.; Palepu, K.G. Winning in Emerging Markets: A Road Map for Strategy and Execution; Harvard Business Press: Cambridge, MA, USA, 2010.

4. Li, Y. The driving factor of corporate social responsibility information disclosure. WTO Econ. Guide 2014, 8, 73-74. (In Chinese)

5. Piotroski, J.D.; Wong, T.J.; Zhang, T. Political bias of corporate news in china: Role of commercialization and conglomeration reforms. J. Law Econ. 2017, 60, 173-207. [CrossRef]

6. Ahern, K.R.; Sosyura, D. Who writes the news? Corporate press releases during merger negotiations. J. Financ. 2014, 69, 241-291. [CrossRef]

7. Gentzkow, M.; Shapiro, J.M. What drives media slant? Evidence from US daily newspapers. Econometrica 2010, 78, 35-71.

8. Gurun, U.; Butler, A. Don't Believe the Hype: Local Media Slant, Local Advertising, and Firm Value. J. Financ. 2012, 67, 561-597. [CrossRef]

9. Solomon, D.H. Selective publicity and stock prices. J. Financ. 2012, 67, 599-638. [CrossRef]

10. Kim, Y.; Li, H.; Li, S. Corporate social responsibility and stock price crash risk. J. Bank. Financ. 2014, 43, 1-13. [CrossRef]

11. Chan, W.S. Stock price reaction to news and no-news: Drift and reversal after headlines. J. Financ. Econ. 2003, 70, 223-260. [CrossRef]

12. Tetlock, P.C. Giving content to investor sentiment: The role of media in the stock market. J. Financ. 2007, 62, 30. [CrossRef]

13. Tetlock, P.C.; Saar-Tsechansky, M.; Macskassy, S. More than words: Quantifying language to measure firms' fundamentals. J. Financ. 2008, 63, 1437-1467. [CrossRef]

14. Aman, H. An analysis of the impact of media coverage on stock price crashes and jumps: Evidence from japan. Pac. Basin Financ. J. 2013, 24, 22-38. [CrossRef]

15. Kim, J.B.; Yu, Z.; Zhang, H. Can media exposure improve stock price efficiency in china and why? China J. Account. Res. 2016, 9, 83-114. [CrossRef]

16. Li, Q.; Wang, T.J.; Li, P.; Liu, L.; Gong, Q.; Chen, Y. The effect of news and public mood on stock movements. Inf. Sci. 2014, 278, 826-840. [CrossRef]

17. Oliveira, N.; Cortez, P.; Areal, N. The impact of microblogging data for stock market prediction: Using twitter to predict returns, volatility, trading volume and survey sentiment indices. Expert Syst. Appl. 2017, 73, 125-144. [CrossRef]

18. Wu, C.H.; Lin, C.J. The impact of media coverage on investor trading behavior and stock returns. Pac. Basin Financ. J. 2017, 43, 151-172. [CrossRef]

19. Farooq, O.; Hamouda, M. Stock price synchronicity and information disclosure: Evidence from an emerging market. Financ. Res. Lett. 2016, 18, 250-254. [CrossRef]

20. Groseclose, T.; Milyo, J. A measure of media bias. Q. J. Econ. 2005, 120, 1191-1237. [CrossRef]

21. Mullainathan, S.; Shleifer, A. The market for news. Am. Econ. Rev. 2005, 95, 1031-1053. [CrossRef]

22. Gentzkow, M.; Shapiro, J.M. Media bias and reputation. J. Polit. Econ. 2006, 114, 280-316. [CrossRef]

23. Reuter, J.; Zitzewitz, E. Do ads influence editors? advertising and bias in the financial media. Q. J. Econ. 2006, 121, 197-227.

24. Rinallo, D.; Basuroy, S. Does advertising spending influence media coverage of the advertiser? J. Mark. 2009, 73, 33-46. [CrossRef]

25. Cahan, S.F.; Chen, C.; Chen, L.; Nguyen, N.H. Corporate social responsibility and media coverage. J. Bank. Financ. 2015, 59, 409-422. [CrossRef]

26. Yang, W.; Lin, D.; Yi, Z. Impacts of the mass media effect on investor sentiment. Financ. Res. Lett. 2017, 22, 1-4. [CrossRef] 
27. Fama, E.F.; French, K.R. Disagreement, tastes, and asset prices. J. Financ. Econ. 2007, 83, 667-689. [CrossRef]

28. Cheung, A. Corporate social responsibility and corporate cash holdings. J. Corp. Financ. 2016, 37, 412-430. [CrossRef]

29. Albuquerque, R.; Durnev, A.; Koskinen, Y. Corporate Social Responsibility and Firm Risk: Theory and Empirical Evidence. CEPR Discussion Papers No. DP9533. 2013. Available online: https://ssrn.com/abstract= 2291334 (accessed on 16 May 2019).

30. McAlister, L.; Srinivasan, R.; Kim, M.C. Advertising, research and development, and systematic risk of the firm. J. Mark. 2007, 71, 35-48. [CrossRef]

31. Luo, X.; Bhattacharya, C. The debate over doing good: Corporate social performance and firm-idiosyncratic risk. J. Mark. 2009, 73, 198-213. [CrossRef]

32. Jo, H.; Na, H. Does CSR reduce firm risk? Evidence from controversial industry sectors. J. Bus. Ethics 2012, 110, 441-456. [CrossRef]

33. Kim, M.C.; Kim, Y.H. Corporate social responsibility and shareholder value of restaurant firms. Int. J. Hosp. Manag. 2014, 40, 120-129. [CrossRef]

34. Park, S.; Song, S.; Lee, S. Corporate social responsibility and systematic risk of restaurant firms: The moderating role of geographical diversification. Tour. Manag. 2017, 59, 610-620. [CrossRef]

35. Oikonomou, I.; Brooks, C.; Pavelin, S. The impact of corporate social performance on financial risk and utility: A longitudinal analysis. Financ. Manag. 2012, 41, 483-515. [CrossRef]

36. El Ghoul, S.; Guedhami, O.; Kwok, C.; Mishra, D. Does corporate social responsibility affect the cost of capital? J. Bank. Financ. 2011, 35, 2388-2406. [CrossRef]

37. Lee, S.; Singal, M.; Kang, K.H. The corporate social responsibility-financial performance link in the U.S. restaurant industry: Do economic conditions matter? Int. J. Hosp. Manag. 2013, 32, 2-10. [CrossRef]

38. Aoki, M. Linking Economic and Social-Exchange Games: From the Community Norm to CSR. In Social Capital, Corporate Social Responsibility, Economic Behaviour and Performance; Sacconi, L., Antoni, G.D., Eds.; Palgrave Macmillan: London, UK, 2011; pp. 129-148.

39. Godfrey, P.C. The relationship between corporate philanthropy and shareholder wealth: A risk management perspective. Acad. Manag. Rev. 2005, 30, 777-798. [CrossRef]

40. Peloza, J. Using corporate social responsibility as insurance for financial performance. Calif. Manag. Rev. 2006, 48, 52-72. [CrossRef]

41. Russo, A.; Perrini, F. Investigating stakeholder theory and social capital: CSR in large firms and SMEs. J. Bus. Ethics 2010, 91, 207-221. [CrossRef]

42. Becchetti, L.; Ciciretti, R.; Hasan, I. Corporate social responsibility, stakeholder risk, and idiosyncratic volatility. J. Corp. Financ. 2015, 35, 297-309. [CrossRef]

43. Habib, A.; Hasan, M.M.; Bhuiyan, M.B.U. Customer Concentration, Corporate Social Responsibility and Idiosyncratic Risk. SSRN Working Paper. 2015. Available online: http://dx.doi.org/10.2139/ssrn.2586588 (accessed on 16 May 2019).

44. Rubin, M. Corporate social responsibility, risk diversification, and firm value: Does corporate social responsibility diversify risk. SSRN Electron. J. 2016. [CrossRef]

45. Mishra, S.; Modi, S.B. Positive and negative corporate social responsibility, financial leverage, and idiosyncratic risk. J. Bus. Ethics 2013, 117, 431-448. [CrossRef]

46. Chen, R.C.Y.; Hung, S.W.; Lee, C.H. Corporate social responsibility and firm idiosyncratic risk in different market states. Corp. Soc. Responsib. Environ. Manag. 2018, 25, 642-658. [CrossRef]

47. Hasan, M.M.; Habib, A. Social capital and idiosyncratic return volatility. Aust. J. Manag. 2019, 44, 3-31. [CrossRef]

48. Koh, P.S.; Qian, C.; Wang, H. Firm Litigation Risk and The Insurance Value of Corporate Social Performance. Strateg. Manag. J. 2014, 35, 1464-1482. [CrossRef]

49. Hockerts, K.A. Cognitive Perspective on the Business Case for Corporate Sustainability. Bus. Strategy Environ. 2015, 24, 102-122. [CrossRef]

50. Kao, H.E.; Shui, Y.M.; Lin, C.H. Does Engagement in Corporate Social Responsibility Reduce Firm Risk? Evidence from China. J. Manag. 2016, 33, 501-529. 
51. Shiu, Y.M.; Yang, S.L. Does Engagement in Corporate Social Responsibility Provide Strategic Insurance-like Effect. Strateg. Manag. J. 2017, 38, 455-470. [CrossRef]

52. Cai, G.W.; Shao, Z.H.; Xu, X.Z. Is there a collusion in business and media? Indirect evidence from media reports of Chinese listed companies. Manag. World 2015, 7, 158-169. (In Chinese) [CrossRef]

(C) 2019 by the authors. Licensee MDPI, Basel, Switzerland. This article is an open access article distributed under the terms and conditions of the Creative Commons Attribution (CC BY) license (http://creativecommons.org/licenses/by/4.0/). 